\title{
Satisfaction of Electricity Distribution Company's Customers in Pune City
}

\author{
Ashok Kurtkoti ${ }^{1}$, Pradeep Sadarpatil ${ }^{2}$ \\ \{ ashokkurtkoti@gmail.com ${ }^{1}$,pradeep_sadar@yahoo.co.in $\left.{ }^{2}\right\}$ \\ ${ }^{1}$ MIT School of Business, Pune, ${ }^{2}$ Faculty of Marketing, ICFAI Business School (IBS) Pune
}

\begin{abstract}
Customer satisfaction gained importance in the last few years. From the domestic customer's perspective, electricity is also one of basic needs apart from food, clothing, and shelter. The dependence for electricity in one's day to day life is almost endless. Power distribution companies are struggling with low customer satisfaction, Electricity Distribution customers complain of higher power tariffs and low service levels. The results reveal that these customers were not satisfied and there was a good scope for improvement.
\end{abstract}

Keywords: Electricity distribution companies, Power sector, Competition, Customer satisfaction, Domestic customers

\section{Introduction}

Today most electricity distribution companies in many countries including India are struggling with low customer satisfaction levels. Electricity customers complain of higher power tariff and very low service levels. Electricity is one of the customer basic needs. Customer satisfaction gained importance in the last few years. The product quality now has major emphasis on customer satisfaction .Customers were the most vital link of the above value-chain in electricity sector. The entire value-chain efficiency depends on how the customer needs were met and the customers were satisfied. From the customer's point of view, electricity was also one more basic need apart from food, clothing and shelter.

Many research papers in relation to the topic were studied. This research paper highlights as to whether these electricity distribution company's domestic customers were satisfied and to find out scope for improvement electricity distribution company's domestic customers

\section{Literature review}

The research papers in relation to the topic were studied and it was found that extensive work was carried out in $\mathrm{UK}^{2}$, USA ${ }^{2}, \mathrm{Japan}^{2}$, Hungary ${ }^{27}$, Sweden, Finland, Poland and Germany ${ }^{8}$ in this regard. 


\subsection{Residential Consumers' choice of Electric Power Supplier in the Electricity Market.}

Based on Survey in Japan, USA. And UK. A published a research paper on the above subject matter by carrying out telephone survey of residential customers; 2,060 and1, 000 respondents in Japan and UK, respectively.

\subsection{Customer Satisfaction Research Work on Electricity Distribution in select countries}

- In U.K- According to U.K's first overall Customer Satisfaction Index- ( NCSI-UK ) companies did a better job in satisfying their customers than the companies in Japan, Sweden, Finland, Denmark, Singapore, Hongkong, Thailand and South Africa but they lagged behind their counterparts in United States, Turkey and Colombia Scottish power was ranked to top position in UK in both on line services and meter reading $.15,16,17$ and Nepal.3

- In U.A.E. and Denmark, Geographic Information System (GIS) used by the utility industry provides more information than visible static map. 20

- In Europe, Vattenfall, an electricity utility company operating in Sweden, Finland, New Zealand, Germany \& Poland.

- Vattenfall started a program called "No 1 for the customer" a few years ago. Within the program several projects were started to improve the customer service and the customer communication. 6

- For an electricity distribution company, both technical and commercial personnel have contacts with the customers to offer services and solve problems for the customers. In order to gain customers trust, Vattenfall started communicating to the customers during and after the interruptions in the supply.6

- In India, Tata Power's focus on Customer Satisfaction- the company had installed an Electronic Drop Box Machine in its consumer's premises Tata Power Energy Club (TPEC) had an Energy Conservation initiative that focused through the enterprise and creativity of Indian Youth! Tata Power sensitizes school children from different schools in Mumbai about energy conservation through talks and audio-visual presentations 18,19 .

\section{Research methodology}

\subsection{Scope of the study}

3.1.1. The scope covers the study of satisfaction of 'domestic customers of distribution company in Pune city.

\subsection{Period of the study}

Study was carried out from January 2017 to June 2017. 
Pune city Domestic Customers of MSEDCL (Power Distribution Company), Pune and Mumbai power distribution company's customers (contacted for benchmarking)

\subsection{Hypothesis Testing}

Used $\mathrm{Z}$ test for testing difference between two means, $\mathrm{Z}$ value for one tail test at $5 \%$ level of significance was considered. Basic tabulation was done using MS Excel

\subsection{Objectives}

1) 1) To study the satisfaction levels of power distribution company's domestic customers in Pune city.

2) To find out scope for improvements for MSEDCL's domestic customers

\subsection{Sample size}

270 numbers domestic customers in Pune city and 48 numbers in Mumbai for benchmarking

\section{Identification of independent variables or attributes}

This research study was carried out by comparing performance attributes of electricity distribution companies in various countries. Research paper on Customer Satisfaction in the Hungarian Electricity Distribution 26 by Terszty'anszky $\mathrm{T}$ and Rekettye.G and is the basis of this research

\section{Statement of the problem}

1. Electricity was one of basic needs of the customer. However, this need was not met by Power Distribution Company as Electricity was not available on a regular basis.

2. Even if power supply was available, there were interruptions.

3. Due to power thefts the honest customers were deprived of power supply even though they were willing to pay

\section{Significance of various attributes considered in the questionnaire}

All attributes were chosen after careful scrutiny and review of literature. A special emphasis was given on relating each attribute to the research topic.

The selected for study were as follows

\section{A. Criticality of service (Connectivity).}

This attribute was of utmost importance from customer's perspective and was determined by the following three criterion- A1. Availability of uninterrupted power supply A2. Speed of restoration of power supply and A3 Minimal voltage fluctuations.

\section{B. Electricity Distribution Company's focus on safety}

\section{Complaint handling system (Connectivity)}


Complaint handling system played a crucial role in determining the customer satisfaction and was divided into 5 criterion as: C5. Response to consumer needs, C6. Timely fault attending, C7. Time taken for administrative procedures, C8. Adequacy in number of receiving points and C9. Speed at which consumer grievance related issues were handled.

\section{Reliability of supply/service (Connectivity)}

If the power was available but was not continuous then it can put the customer in to a lot of inconvenience and to satisfy customers', continuity of power supply was a must and decided by D10.

\section{B. Quality of supply/service (Connectivity)}

Quality of supply/service determined by the following criterion: E11. Availability of smooth supply, E12. Exactness of work done by electricity distribution company employee. E13. Compliance to safety norms by electricity distribution company employee.

\section{Accurate and punctual meter reading (Commerce)}

The proper functioning of meter and timely recording of meter readings played a very important role in customer satisfaction and the critreion required to be considered for understanding the same were: F14. Frequency of meter reading. F15. Specific date of meter reading and F16. Reliability of meter reading.

\section{Accuracy and reliability of billing ( Commerce)}

Billing was an area where there were many issues interlinked and was closely related to metering and power thefts. Over billing kept customer satisfaction low whereas under billing affected the financial performance of Electricity Distribution Company. Also, timely bill distribution and ease of bill acceptance and clearance played a crucial role in keeping customer satisfied. The eight-criterion considered for this attribute were: G17. Clarity on details of bill, G18. Conformity of bill to the consumption, G19. Bill distribution at delivery point, G20. Bill not received 2 weeks before due date, G21. Response on incorrect bill, G22. Speed at which duplicate bill is issued, G23. Time lag for reconnection after the payment, G24. Reliability of electronic clearing system.

\section{H. Power Tariff (Commerce)}

No consumer will be willing to pay higher power tariff unless price revision was done with proper communications and justification on enhanced services by Electricity Distribution Company. The criterion used for these attributes were: H25. Present power tariff, H26.Are you aware of revision in the present power tariff? A. Yes, b. No and c. If yes, how did you become aware of it?

\section{Interaction with customers (Communication)}

In order to gain customers' trust, MSECDL must communicate to the customers during and after the interruptions in the supply as well as during any queries from the customers. Also to improve customer satisfaction it was also important to communicate reliable and improved communication. The information given to the customer should be honest and accurate. This attribute decided on 4 criterion such as 1 . Interactive customer's service, 2. Customer telephonic service, 3 Communication via the internet and4.Communication via a newsletter. 
J. Measures taken by electricity Distribution Company in detecting and control of power thefts (Commerce)

Power thefts lead to higher distribution losses and an honest customer was dissatisfied as he or she was deprived of getting power supply during power shortage. 3 criterion for this purpose were: J31. Clear case of power theft, J32. Authorized connection but tampered meter, J33. Action tken on power

\section{Market survey results}

Analysis and its interpretation of data of 4 electricity distribution companies in Mumbai and MSEDCL, Pune with the purpose of benchmarking for domestic Customers

Customers of 4 electricity distribution companies in Mumbai, namely, Tata Power, BSET, Reliance Energy and MSDECL, Mumbai and MSEDCL Pune are surveyed for benchmarking purpose. For this purpose, all the attributes are taken into consideration for both domestic and industrial customers. Their response regarding the importance and satisfaction for each and every attribute and criterion is scaled as 0-100 points. The gaps between the satisfaction and importance are calculated by subtracting importance from satisfaction, to measure the underperformance or over performance of each electricity distribution company for each point. As calculations are done in MSExcel, there is a possibility of 0.1 difference in gaps.

\section{Attribute wise data analysis and its interpretation for domestic customers}

Attribute wise analysis of gaps and its interpretation for domestic customers is given below

Table 1. Criticality of service (The customer responses to criticality of service were given in the following Table 1 and Fig 1)

\begin{tabular}{|l|l|l|l|l|}
\hline Critreion & Company & $\begin{array}{l}\text { Importance } \\
\text { (I) }\end{array}$ & $\begin{array}{l}\text { Satisfaction } \\
\text { (S) }\end{array}$ & $\begin{array}{l}\text { Gap= } \\
\text { (S- I) }\end{array}$ \\
\hline $\begin{array}{l}\text { A1. Uninterrupted } \\
\text { power supply }\end{array}$ & MSEDCL, Mumbai & 100.0 & 53.3 & -46.7 \\
& Tata Power & 100.0 & 98.3 & -1.7 \\
& Reliance Energy & 100.0 & 73.3 & -26.7 \\
& BEST & 100.0 & 85.0 & -15.0 \\
& MSEDCL Pune & 100.0 & 26.7 & -73.3 \\
\hline $\begin{array}{l}\text { A2. Speed of restoration } \\
\text { of power supply }\end{array}$ & MSEDCL Mumbai & 100.0 & 56.7 & -43.3 \\
& Tata Power & 100.0 & 100.0 & 0.0 \\
& Reliance Energy & 100.0 & 70.0 & -30.0 \\
& BEST & 100.0 & 78.3 & -21.7 \\
\hline $\begin{array}{l}\text { A3. Minimal voltage } \\
\text { fluctuations }\end{array}$ & MSEDCL Pune & 100.0 & 31.7 & -68.3 \\
& MSEDCL Mumbai & 100.0 & 43.3 & -56.7 \\
& Tata Power & 100.0 & 100.0 & 0.0 \\
& Reliance Energy & 100.0 & 75.0 & -25.0 \\
& BEST & 98.3 & 86.7 & -11.6 \\
& MSEDCL Pune & 100.0 & 26.7 & -73.3 \\
\hline
\end{tabular}




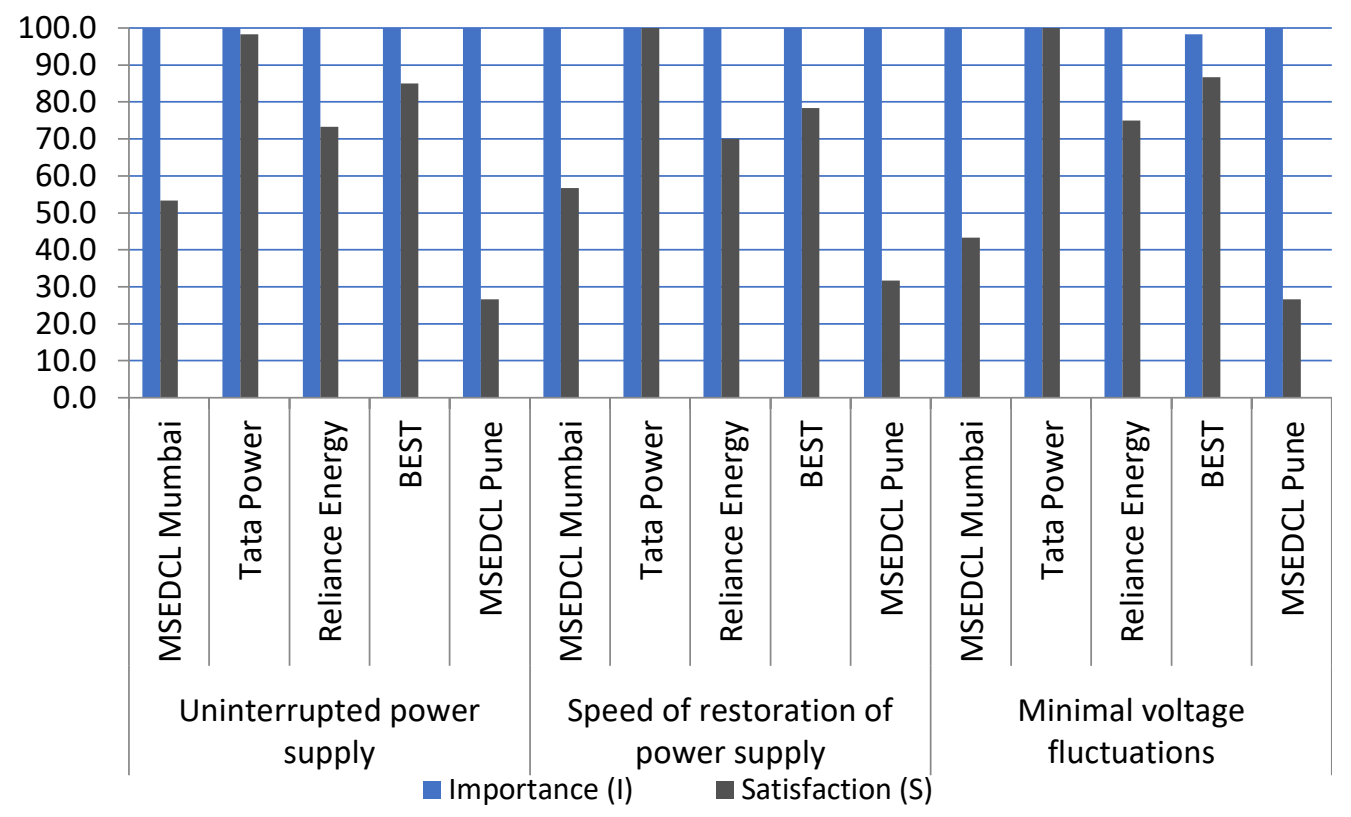

Fig. 1: Criticality of service

Data analysis of gaps and its interpretation

1. Consumer's safety aspect was examined with the help of focus on safety of various electricity distribution companies. Least gap of -1.7 points was observed with Tata Power.

2. Highest gap was observed with MSEDCL Mumbai at -53.3 point

3. Reliance -26.7 points) and $\operatorname{BEST}$ ( -31.7 points) showed less gap than MSEDCL, Pune(- 45.0 points)

Table 2. Consumer's safety (The costumer response to consumer's safety are given in Table 2 and Fig. 2 below.

\begin{tabular}{|l|l|l|l|l|}
\hline Critreion & Company & $\begin{array}{l}\text { Importance } \\
(\mathbf{I})\end{array}$ & $\begin{array}{l}\text { Satisfaction } \\
\text { (S) }\end{array}$ & $\begin{array}{l}\text { Gap= } \\
\text { (S-I) }\end{array}$ \\
\hline $\begin{array}{l}\text { B4. Focus on } \\
\text { safety }\end{array}$ & MSEDCL Mumbai & 100.0 & 46.7 & -53.3 \\
& & 100.0 & 98.3 & -1.7 \\
& Tata Power & 100.0 & 73.3 & -26.7 \\
& Reliance Energy & 96.7 & 65.0 & -31.7 \\
& BEST & 100.0 & 55.0 & -45.0 \\
\hline
\end{tabular}




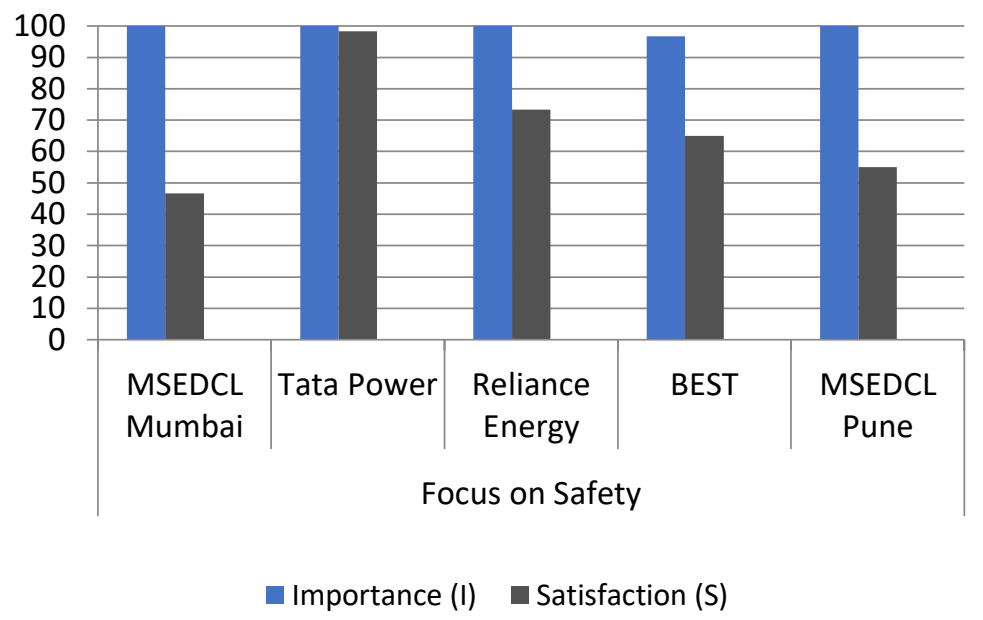

Fig. 2 Consumer's safety

Data analysis of gaps and its interpretation

1. Consumer's safety aspect was examined with the help of focus on safety of various electricity distribution companies. Least gap of -1.7 points was observed with Tata Power.

2. Highest gap was observed with MSEDCL Mumbai at -53.3 point

3. Reliance -26.7 points) and $\operatorname{BEST}$ ( -31.7 points) showed less gap than MSEDCL, Pune(- 45.0 points) 
Table 3. Complaint handling system (The customer responses to complaint handling system are given in the following Table 3 and Fig. 3)

\begin{tabular}{|c|c|c|c|c|}
\hline Critreion & Company & Importance(I) & Satisfaction(S) & Gap $=($ S-I $)$ \\
\hline $\begin{array}{l}\text { "C5. Response } \\
\text { to customer need }\end{array}$ & $\begin{array}{l}\text { MSEDCL Mumbai } \\
\text { Tata Power } \\
\text { Reliance Energy } \\
\text { BEST } \\
\text { MSEDCL Pune }\end{array}$ & $\begin{array}{l}90.0 \\
100.0 \\
85.0 \\
85.0 \\
100.0\end{array}$ & $\begin{array}{l}48.3 \\
93.3 \\
58.3 \\
70.0 \\
26.7\end{array}$ & $\begin{array}{l}-41.7 \\
-6.7 \\
-26.7 \\
-15.0 \\
-73.3\end{array}$ \\
\hline $\begin{array}{l}\text { C6. Timely fault } \\
\text { attending }\end{array}$ & $\begin{array}{l}\text { MSEDCL Mumbai } \\
\text { Tata Power } \\
\text { Reliance Energy } \\
\text { BEST } \\
\text { MSEDCL Pune }\end{array}$ & $\begin{array}{l}95.0 \\
100.0 \\
85.0 \\
90.0 \\
100.0\end{array}$ & $\begin{array}{l}50.0 \\
93.3 \\
58.3 \\
71.7 \\
23.3\end{array}$ & $\begin{array}{l}-45.0 \\
-6.7 \\
-26.7 \\
-18.3 \\
-76.7\end{array}$ \\
\hline $\begin{array}{l}\text { C7. Time taken } \\
\text { for } \\
\text { administrative } \\
\text { procedures }\end{array}$ & $\begin{array}{l}\text { MSEDCL Mumbai } \\
\text { Tata Power } \\
\text { Reliance Energy } \\
\text { BEST } \\
\text { MSEDCL Pune }\end{array}$ & $\begin{array}{l}80.0 \\
86.7 \\
93.3 \\
80.0 \\
86.7\end{array}$ & $\begin{array}{l}46.7 \\
85.0 \\
45.0 \\
58.3 \\
31.7\end{array}$ & \begin{tabular}{l|}
-33.3 \\
-1.7 \\
-48.3 \\
-21.7 \\
-55.0
\end{tabular} \\
\hline $\begin{array}{l}\text { C8. Adequacy in } \\
\text { number } \\
\text { receiving points }\end{array}$ & $\begin{array}{l}\text { MSEDCL Mumbai } \\
\text { Tata Power } \\
\text { Reliance Energy } \\
\text { BEST } \\
\text { MSEDCL Pune }\end{array}$ & $\begin{array}{l}76.7 \\
91.7 \\
88.3 \\
80.0 \\
\\
\end{array}$ & $\begin{array}{l}48.3 \\
86.7 \\
46.7 \\
58.2 \\
28.3 \\
\end{array}$ & $\begin{array}{l}-28.4 \\
-5.0 \\
-41.7 \\
-21.8 \\
-53.4\end{array}$ \\
\hline $\begin{array}{l}\text { C9. Speed at } \\
\text { which consumer } \\
\text { grievance } \\
\text { related issues are } \\
\text { handled }\end{array}$ & $\begin{array}{l}\text { MSEDCL Mumbai } \\
\text { Tata Power } \\
\text { Reliance Energy } \\
\text { BEST } \\
\text { MSEDCL Pune }\end{array}$ & $\begin{array}{l}93.3 \\
98.3 \\
90.0 \\
88.3 \\
91.7\end{array}$ & $\begin{array}{l}40.0 \\
90.0 \\
50.0 \\
55.0 \\
30.0\end{array}$ & \begin{tabular}{l|}
-53.3 \\
-8.3 \\
-40.0 \\
-33.3 \\
-61.7
\end{tabular} \\
\hline
\end{tabular}




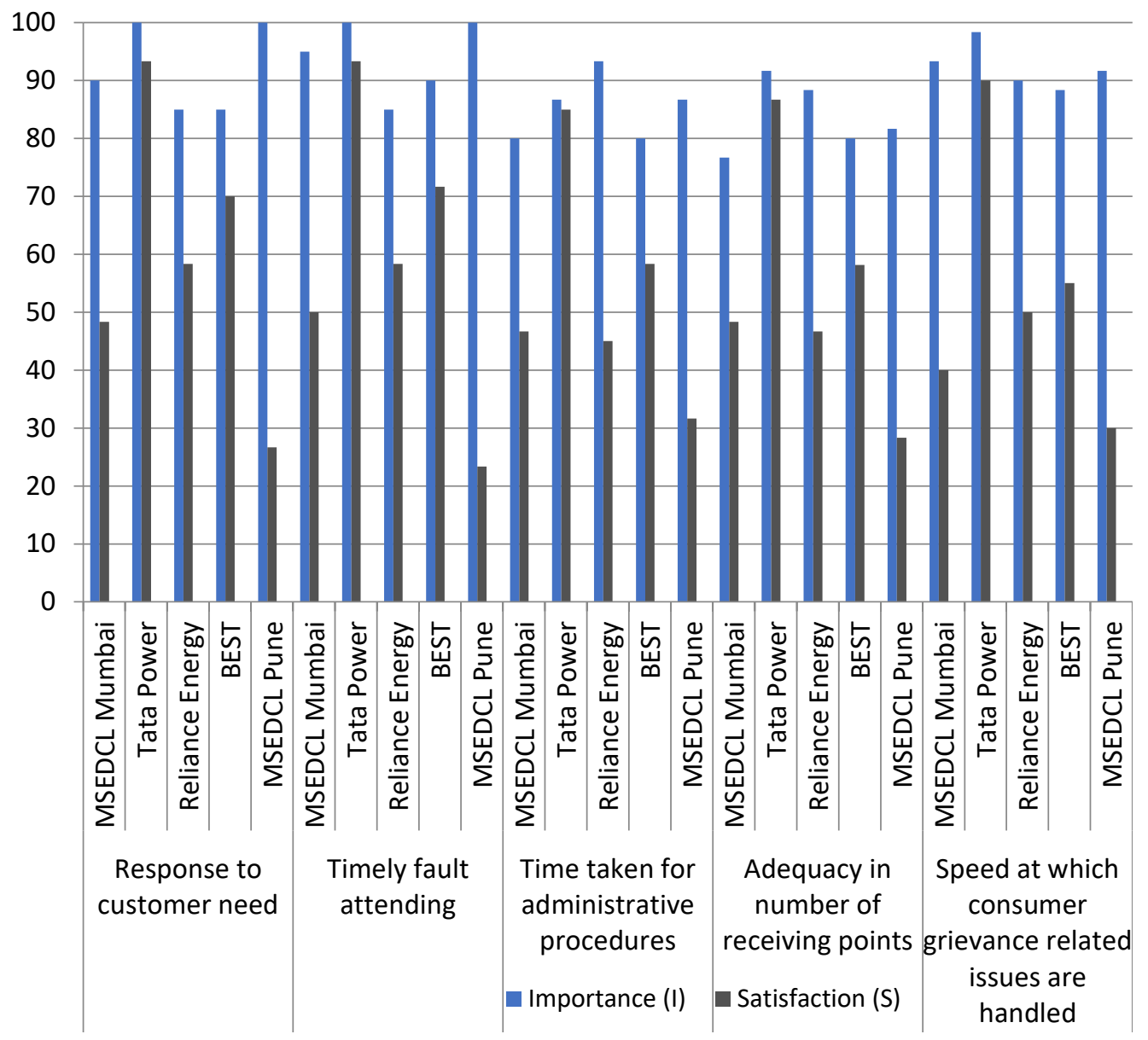

Fig. 3 Complaint handling system

Data analysis of gaps and its interpretation

1. The least pointwise gaps of $-6.7,-6.7,-1.7,-5.0$ and -8.3 respectively were observed for Tata Power. That means that there was underperformance of the company for these criterions to that extent.

2. All Mumbai electricity distribution companies handled complaint handling system better than MSEDCL, Pune. 
Table 4. Reliability of supply (The following Tab.4 and Fig.4 gives customer responses to reliability of suppply/service)

\begin{tabular}{|l|l|l|l|l|}
\hline Critreion & Company & $\begin{array}{l}\text { Importance } \\
(\mathbf{I})\end{array}$ & $\begin{array}{l}\text { Satisfaction } \\
(\text { S) }\end{array}$ & $\begin{array}{l}\text { Gap= } \\
(\text { S-I) }\end{array}$ \\
\hline D10. Continuity of & MSEDCL Mumbai & 90.0 & 31.7 & -58.3 \\
power supply & Tata Power & 98.3 & 96.7 & -1.7 \\
& Reliance Energy & 95.0 & 50.0 & -45.0 \\
& BEST & 92.0 & 60.0 & -32.0 \\
& MSEDCL Pune & 96.7 & 25.0 & -71.7 \\
\hline
\end{tabular}

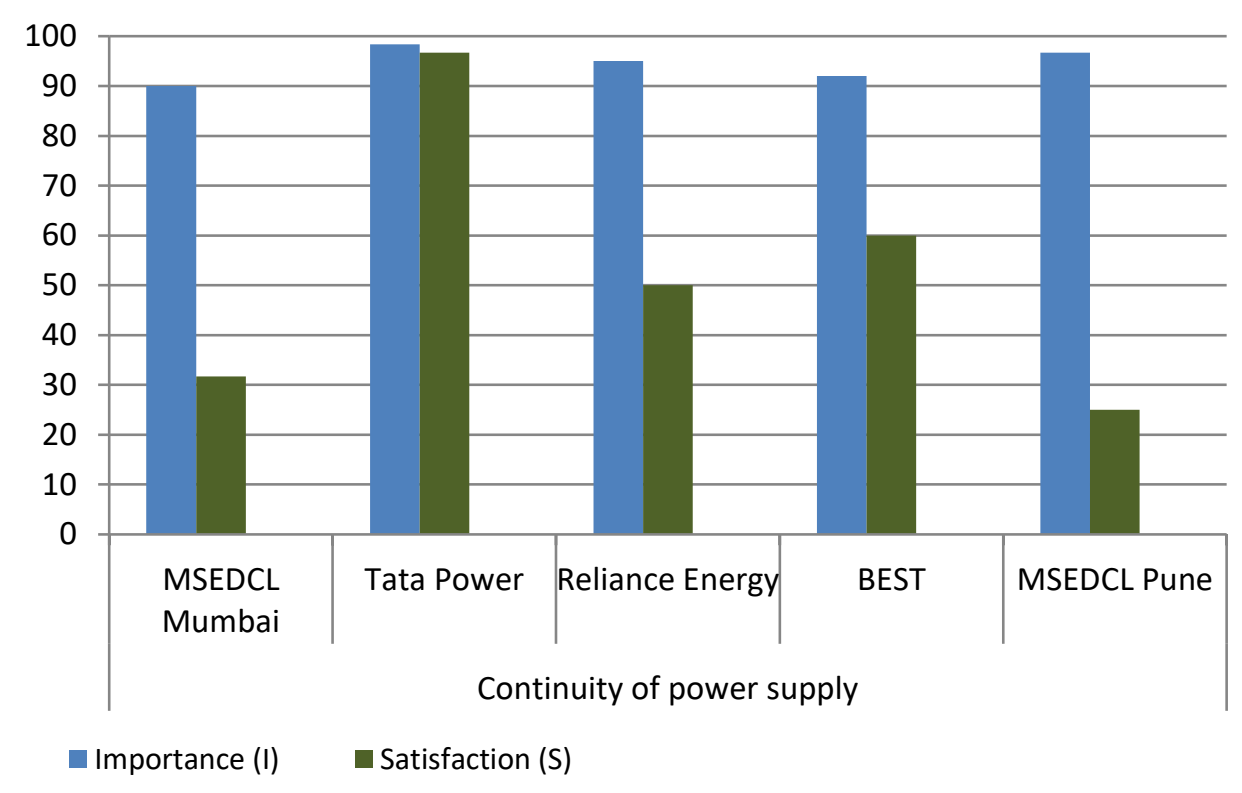

Figure 4.

Data analysis of gaps and its interpretation

1. Reliability of supply / service aspect is examined with the help of continuity of power supply of various electricity distribution companies.

2. Least gap of -1.7 points was observed with Tata Power.

3. Highest gap of -71.7 points was observed with MSEDCL Pune.

4. Mumbai companies Energy (- 45.0 points) and BEST (-32.0 points) have indicated less gaps than MSEDCL, Mumbai (-58.3 points).

5. With frequent interruptions in supply of both MSEDCL companies, their customers were less satisfied than those of other electricity distribution companies. 
Table 5. Quality of supply (Table 5 and Fig 5. gives customer responses to quality of supply/service)

\begin{tabular}{|c|c|c|c|c|}
\hline Criteria & Com & $\begin{array}{l}\text { Importance } \\
\text { (I) }\end{array}$ & $\begin{array}{l}\text { Satisfaction } \\
\text { (S) }\end{array}$ & $\begin{array}{l}\text { Gap= } \\
\text { (S-I) }\end{array}$ \\
\hline $\begin{array}{l}\text { E11. Availability of } \\
\text { smooth power supply. }\end{array}$ & $\begin{array}{l}\text { MSEDCL Mumbai } \\
\text { Tata Power } \\
\text { Relaance E nergy } \\
\text { BEST } \\
\text { MSEDCL Pune }\end{array}$ & $\begin{array}{l}95.0 \\
98.3 \\
98.3 \\
100.0 \\
96.7\end{array}$ & $\begin{array}{l}31.7 \\
100.0 \\
75.0 \\
90.0 \\
23.3\end{array}$ & $\begin{array}{l}-63.3 \\
1.7 \\
-23.3 \\
-10.0 \\
-73.4\end{array}$ \\
\hline $\begin{array}{l}\text { E12. Exactness of } \\
\text { work by electricity } \\
\text { distribution company } \\
\text { employee }\end{array}$ & $\begin{array}{l}\text { MSEDCL Mumbai } \\
\text { Tata Power } \\
\text { Reliance Energy } \\
\text { BEST } \\
\text { MSEDCL Pune }\end{array}$ & $\begin{array}{l}85.0 \\
98.3 \\
88.3 \\
\\
83.6 \\
98.3\end{array}$ & $\begin{array}{l}48.3 \\
96.7 \\
65.0 \\
\\
63.6 \\
43.3\end{array}$ & $\begin{array}{l}-36.7 \\
-1.7 \\
-23.3 \\
-20.0 \\
-55.0\end{array}$ \\
\hline $\begin{array}{l}\text { E13. Compliance to } \\
\text { safety norms by } \\
\text { electricity distribution } \\
\text { company employee }\end{array}$ & $\begin{array}{l}\text { MSEDCL Mumbai } \\
\text { Tata Power } \\
\text { Reliance Energy } \\
\text { BEST } \\
\text { MSEDCL Pune }\end{array}$ & $\begin{array}{l}85.0 \\
98.3 \\
88.3 \\
90.9 \\
98.3\end{array}$ & $\begin{array}{l}43.3 \\
96.7 \\
61.7 \\
65.5 \\
43.3\end{array}$ & $\begin{array}{l}-41.7 \\
-1.7 \\
-26.6 \\
-25.4 \\
-55.0\end{array}$ \\
\hline
\end{tabular}

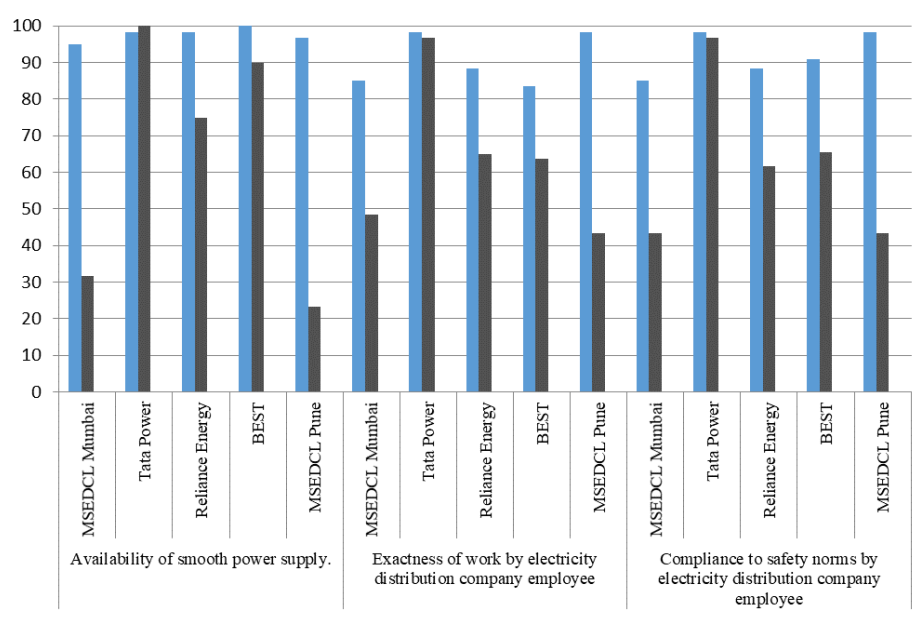

- Importance (I) = Satisfaction (S)

Fig. 5: Quality of supply/service 
Data analysis of gaps and its interpretation

1. The least pointwise gaps of 1.7, -1.7 and -1.7 are observed for Tata Power. That means that there was customer delight of 1.7 points for availability of smooth power supply However for the remaining two criterions, the company underperformed and showed a gap of -1.7 points each.

2. The observed gap for MSEDCL Pune was -73.4 points , -55.0 points and -55.0 points respectively, indicating underperformance

3. Next to Tata Power, BEST customers were satisfied with the quality company for these criterions. of service attribute with pointwise gaps of -10.0, - 20.0, and - 25.4 against all criterion listed above.

4. Both MSEDCL companies showed underperformance against this attribute. MSEDCL, Mumbai showed pointwise gaps of $-63.3,-36.7-41.7$ respectively against all criterion.

5. Reliance Energy showed pointwise gaps of $-23.3,-23.3$, and -26.6 respectively against all criterion.

Table 6. Accurate and punctual meter reading (The following Table 6 and Fig 6 gives responses from customers for accurate and punctual meter reading)

\begin{tabular}{|l|l|l|l|l|}
\hline Critreion & Company & $\begin{array}{l}\text { Importance } \\
(\mathbf{I})\end{array}$ & $\begin{array}{l}\text { Satisfaction } \\
(\mathbf{S})\end{array}$ & $\begin{array}{l}\text { Gap= } \\
(\text { S-I })\end{array}$ \\
\hline $\begin{array}{l}\text { F14. Frequency of } \\
\text { meter reading }\end{array}$ & MSEDCL Mumbai & 88.3 & 45.0 & -43.3 \\
& Tata Power & 95.0 & 90.0 & -5.0 \\
& Reliance Energy & 98.3 & 28.3 & -70.0 \\
& BEST & 90.0 & 46.7 & -43.3 \\
& MSEDCL Pune & 100.0 & 31.7 & -68.3 \\
\hline $\begin{array}{l}\text { F15. Specific date of } \\
\text { meter reading }\end{array}$ & MSEDCL Mumbai & 76.7 & 43.3 & -33.4 \\
& Tata Power & 93.3 & 86.7 & -6.6 \\
& Reliance Energy & 96.7 & 28.3 & -68.4 \\
& BEST & 91.7 & 33.3 & -58.4 \\
F16. Reliability of & MSEDCL Pune & 98.3 & 38.3 & -60.0 \\
meter reading & MSEDCL Mumbai & 96.7 & 51.7 & -45.0 \\
& Tata Power & 100.0 & 100.0 & 0.0 \\
& Reliance Energy & 98.3 & 70.0 & -28.3 \\
& BEST & 91.7 & 70.0 & -21.7 \\
& MSEDCL Pune & 100.0 & 73.3 & -26.7 \\
\hline
\end{tabular}




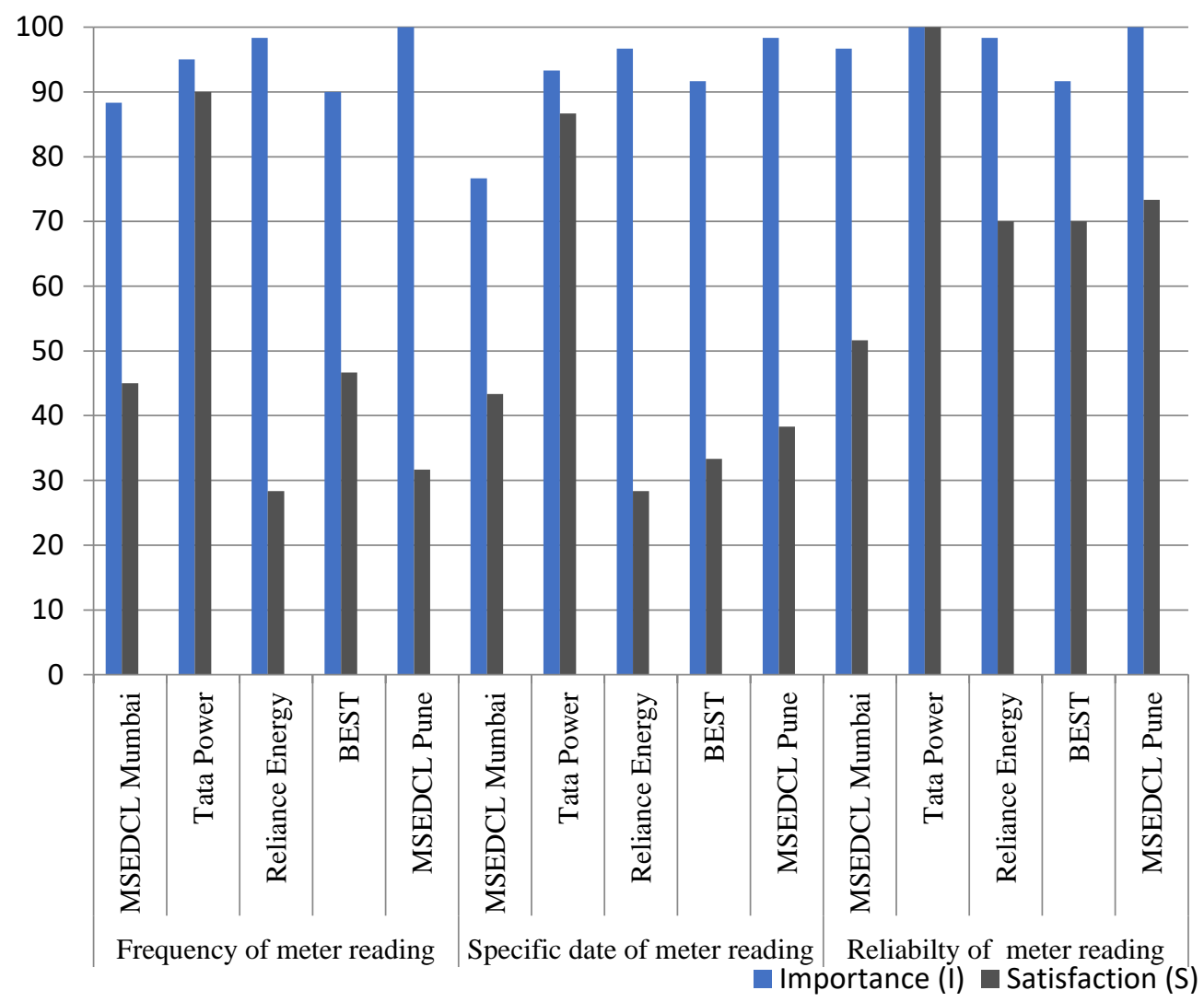

Data analysis of gaps and its interpretation

1. The least pointwise gaps were observed for Tata Power at -5.0 points, -6.6 points and 0 points respectively. That means that there was underperformance of the company of -5.0 points for frequency of meter reading and of -6.6 points for specific date of meter reading. However, for the criterion of reliability of meter reading, the company performed up to the expectations of customers.

2. The highest gap observed was : -68.3 points and -60.0 points with MSEDCL Pune for the first two criterion and - 45.0 points with MSEDCL Mumbai for third criterion, indicating underperformance of the electricity distribution companies for these criterions.

3. For Reliance Energy and BEST the pointwise gaps were -70.0 points, -68.4 points, 28. 
Table 7. Accuracy \& reliability of billing (The following Table 7 , Fig.7a and7.b gives responses from the customers for accuracy \& reliability of billing)

\begin{tabular}{|c|c|c|c|c|}
\hline Critreion & Company & Importance (I) & $\begin{array}{l}\text { Satisfaction } \\
\text { (S) }\end{array}$ & $\begin{array}{l}\text { Gap= } \\
- \text { I) }\end{array}$ \\
\hline G17. Clarity on details of bill. & $\begin{array}{l}\text { MSEDCL } \\
\text { Mumbai } \\
\text { Tata } \\
\text { Power } \\
\text { Reliance } \\
\text { Energy } \\
\text { BEST } \\
\text { MSEDCL } \\
\text { Pune }\end{array}$ & $\begin{array}{l}100.0 \\
100.0 \\
96.7 \\
98.3 \\
91.7\end{array}$ & $\begin{array}{l}45.0 \\
96.7 \\
46.7 \\
45.0 \\
60.0\end{array}$ & $\begin{array}{l}-55.0 \\
-3.3 \\
-50.0 \\
-53.3 \\
-31.7\end{array}$ \\
\hline $\begin{array}{l}\text { G18. Conformity of bill to the } \\
\text { consumption }\end{array}$ & $\begin{array}{l}\text { MSEDCL } \\
\text { Mumbai } \\
\text { Tata } \\
\text { Power } \\
\text { Reliance } \\
\text { Energy } \\
\text { BEST } \\
\text { MSEDCL } \\
\text { Pune }\end{array}$ & $\begin{array}{l}100.0 \\
100.0 \\
96.7 \\
86.7 \\
100.0\end{array}$ & $\begin{array}{l}58.3 \\
100.0 \\
61.7 \\
56.7 \\
78.2\end{array}$ & $\begin{array}{l}-41.7 \\
0.0 \\
-35.0 \\
-30.0 \\
-21.8\end{array}$ \\
\hline G19. Bill distribution at delivery point & $\begin{array}{l}\text { MSEDCL } \\
\text { Mumbai } \\
\text { Tata } \\
\text { Power } \\
\text { Reliance } \\
\text { Energy } \\
\text { BEST } \\
\text { MSEDCL } \\
\text { Pune }\end{array}$ & $\begin{array}{l}90.9 \\
100.0 \\
93.3 \\
88.3 \\
90.9\end{array}$ & $\begin{array}{l}34.5 \\
96.7 \\
45.0 \\
56.7 \\
34.5\end{array}$ & $\begin{array}{l}-56.4 \\
-3.3 \\
-48.3 \\
-31.6 \\
-56.4\end{array}$ \\
\hline $\begin{array}{l}\text { G20. Bill not received } 2 \text { weeks before due } \\
\text { date }\end{array}$ & $\begin{array}{l}\text { MSEDCL } \\
\text { Mumbai } \\
\text { Tata } \\
\text { Power } \\
\text { Reliance } \\
\text { Energy } \\
\text { BEST } \\
\text { MSEDCL } \\
\text { Pune }\end{array}$ & $\begin{array}{l}93.3 \\
100.0 \\
95.0 \\
86.7 \\
100.0\end{array}$ & $\begin{array}{l}40.0 \\
98.3 \\
51.7 \\
53.3 \\
33.3\end{array}$ & $\begin{array}{l}-53.3 \\
-1.7 \\
-43.3 \\
-33.4 \\
-66.7\end{array}$ \\
\hline G21. Response on incorrect bill & $\begin{array}{l}\text { MSEDCL } \\
\text { Mumbai } \\
\text { Tata } \\
\text { Power } \\
\text { Reliance } \\
\text { Energy } \\
\text { BEST } \\
\text { MSEDCL } \\
\text { Pune }\end{array}$ & $\begin{array}{l}91.7 \\
100.0 \\
94.5 \\
85.0 \\
100.0\end{array}$ & $\begin{array}{l}40.0 \\
96.0 \\
49.1 \\
45.0 \\
43.3\end{array}$ & $\begin{array}{l}-51.7 \\
-4.0 \\
-45.4 \\
-40.0 \\
-56.7\end{array}$ \\
\hline $\begin{array}{l}\text { G22. Speed at which duplicate bill is } \\
\text { issued }\end{array}$ & $\begin{array}{l}\text { MSEDCL } \\
\text { Mumbai }\end{array}$ & 90.0 & 41.7 & -48.3 \\
\hline
\end{tabular}




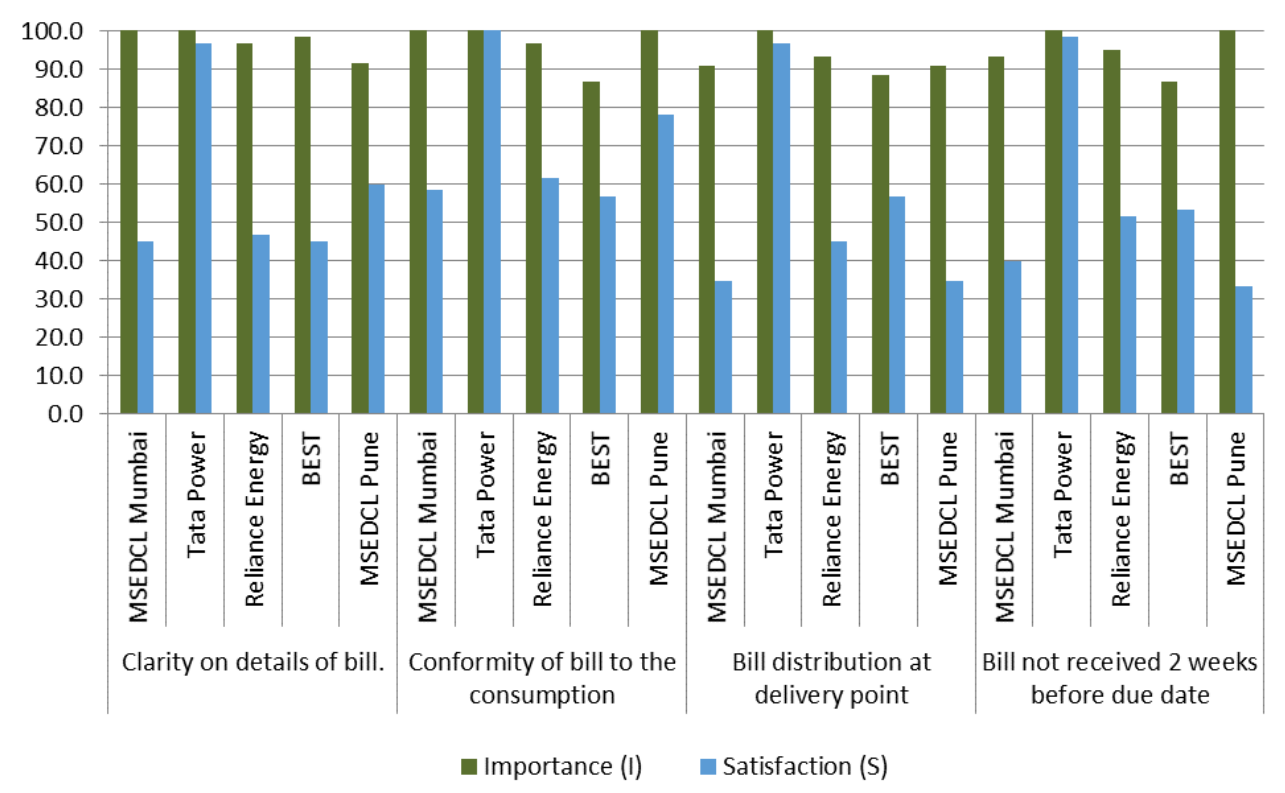

Fig 7a.: Accuracy \& reliability of billing

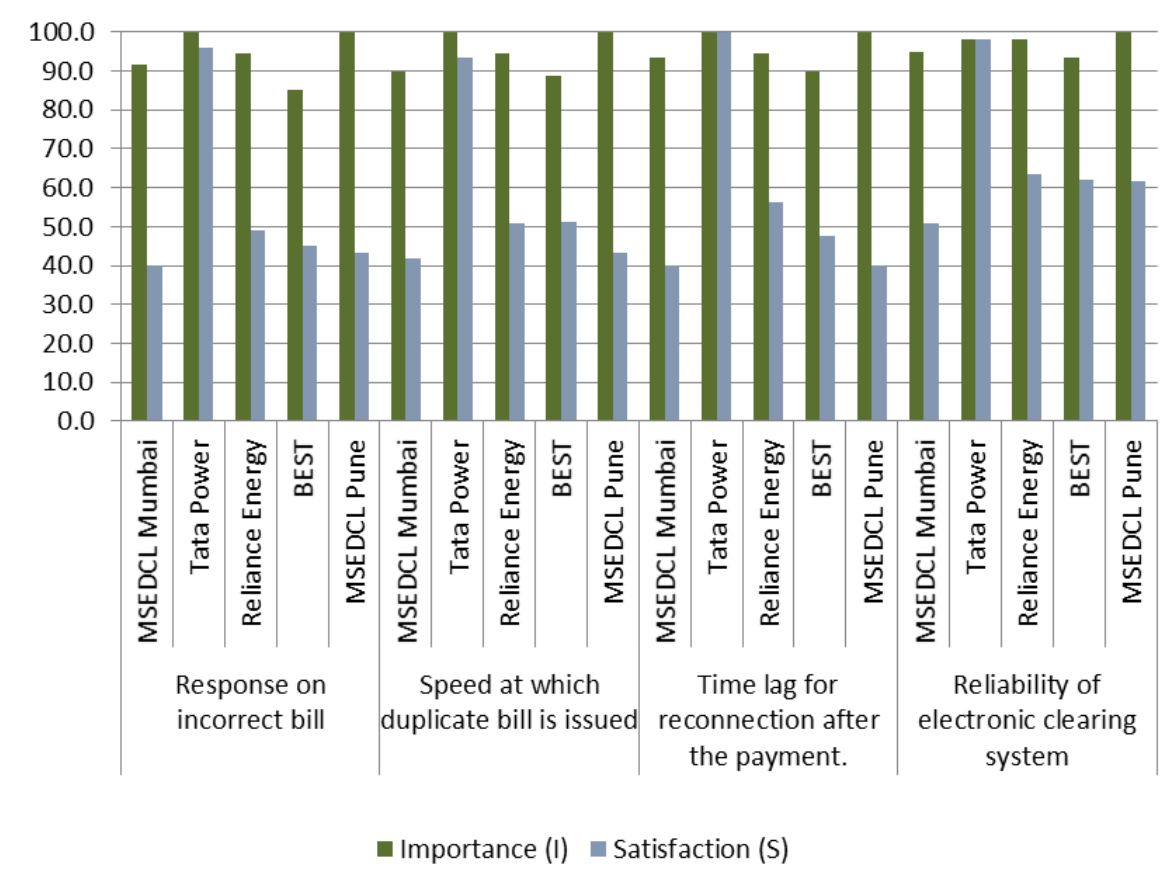

igure 7b.: Accuracy \& reliability of billing 
Data analysis of gaps and its interpretation

1. Least pointwise gaps were noticed in Tata Power for all criterion with pointwise gaps as : $-3.3,-0 .-3.3,-1.7,-4.0,-6.7,-0,-0$ respectively.

2. MSEDCL, Mumbai showed pointwise gaps of -55.0 , -41.7, - 56.4, -53.3, -51.7,$48.3,-53.3,-44.1$ for criterion listed above. This indicated highest gaps and least customer satisfaction with the following criterion.

3. MSEDCL, Pune showed pointwise gaps of -31.7, -21.8, -56.4, - 66.7, -56.7, -56.7, $60,-38.2$ respectively against all criteria listed above. This indicated highest gaps and the least customer satisfaction with criterion such as:

a. G20.Bills not received 2 weeks before due date,

b. G21. Response to incorrect bill,

c. G22. Speed at which duplicate bill is issued and

d. G23. Time lag for reconnection after the payment.

4. BEST indicated pointwise gaps of $-53.3,-30.0,-31.6,-33.4,-40.0,-37.8,-42.5,-31.1$ for all criterion.

5. Reliance Energy indicated pointwise gaps of -50.0, -35.0, -48.3, -43.3, -45.4, -43.6, 38.1, -34.6 for all criterion.

Table 8. Power tariff (The following Table 8 and Fig. 8 gives responses from the customers for power tariff)

\begin{tabular}{|c|c|c|c|c|c|}
\hline Critreion & Company & & $\begin{array}{l}\text { Importance } \\
\text { (I) }\end{array}$ & $\begin{array}{l}\text { Satisfaction } \\
\text { (S) }\end{array}$ & $\begin{array}{l}\text { Gap = } \\
(\mathrm{S}-\mathrm{I})\end{array}$ \\
\hline $\begin{array}{l}\mathrm{H} 25 \text {. Present } \\
\text { power tariff }\end{array}$ & $\begin{array}{l}\text { MSEDCL Mumbai } \\
\text { Tata Power } \\
\text { Reliance Energy } \\
\text { BEST } \\
\text { MSEDCL Pune }\end{array}$ & 100.0 & $\begin{array}{l}96.7 \\
98.2 \\
100.0 \\
100.0 \\
32.7\end{array}$ & $\begin{array}{l}35.0 \\
98.2 \\
28.3 \\
30.0 \\
-67.3\end{array}$ & $\begin{array}{l}-61.7 \\
0.0 \\
-71.7 \\
-70.0\end{array}$ \\
\hline
\end{tabular}




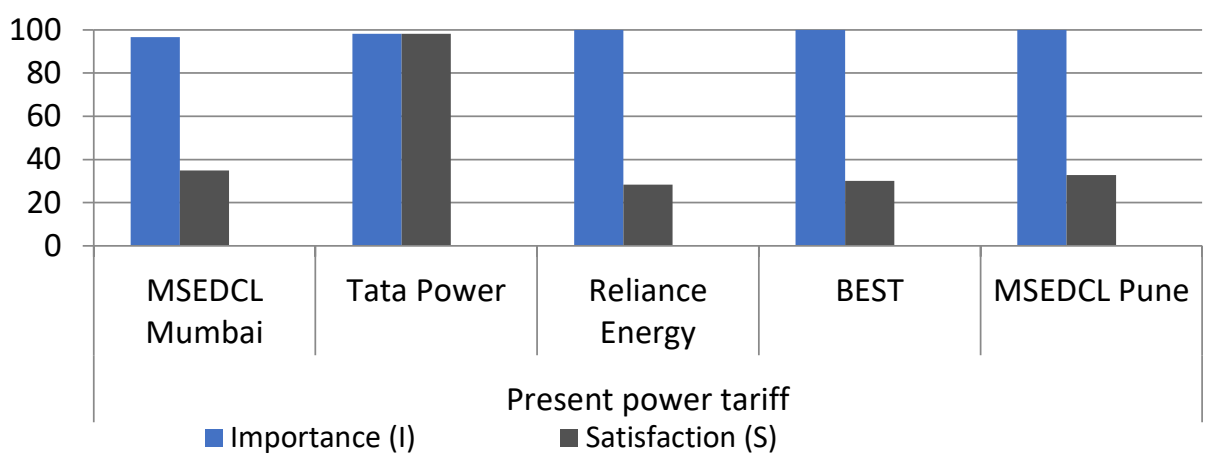

Fig. 8: Power tariff

Data analysis of gaps and its interpretation-

1. Least gap of 0 points is observed with Tata Power.

2. Highest gap of- 71.7 points was noticed with Reliance Energy.

3. The gap in case of MSEDCL, Mumbai was - 61.7 points.

4. MSEDCL, Pune showed a gap of - 67.3points.

5. BEST indicated a gap of -70.0 points 
Table 9. Interaction with customers Interaction with customers (The customer responses are given in the following Table 9 and Fig.9 for interaction with customers)

\begin{tabular}{|c|l|c|c|c|}
\hline Criterion & \multicolumn{1}{|c|}{ Company } & Importance & Satisfaction & Gap $=(\mathbf{S}-\mathbf{I})$ \\
\hline & MSEDCL Mumbai & 85.0 & 38.3 & -46.7 \\
I26. Interactive & Tata Power & 100.0 & 98.3 & -1.7 \\
customer service & Reliance Energy & 85.0 & 48.3 & -36.7 \\
& BEST & 91.7 & 43.3 & -48.4 \\
& MSEDCL Pune & 95.0 & 35.0 & -60.0 \\
\hline & MSEDCL Mumbai & 73.3 & 30.0 & -43.3 \\
I27. Customer & Tata Power & 96.7 & 93.4 & -3.3 \\
teleservice & Reliance Energy & 80.0 & 36.7 & -43.3 \\
& BEST & 76.7 & 38.3 & -38.4 \\
& MSEDCL Pune & 83.3 & 30.0 & -53.3 \\
\hline & MSEDCL Mumbai & 71.7 & 26.7 & -45.0 \\
I28. Communication & Tata Power & 100.0 & 98.3 & -1.7 \\
via the Internet & Reliance Energy & 70.0 & 25.0 & -45.0 \\
& BEST & 75.6 & 20.0 & -55.6 \\
& MSEDCL Pune & 78.3 & 25.0 & -53.3 \\
\hline & MSEDCL Mum 'bai & 46.7 & 20.0 & -26.7 \\
I29. Communication & Tata Power & 100.0 & 100.0 & 0.0 \\
via a newsletter & Reliance Energy & 61.7 & 26.7 & -35.0 \\
& BEST & 75.0 & 20.0 & -55.0 \\
& MSEDCL Pune & 50.0 & 21.7 & -28.3 \\
\hline
\end{tabular}

Fig. 9: Interaction with customers

Data analysis of gaps and its interpretation

1. Least pointwise gaps of $-1.7,-3.3,-1.7,0$ were observed for Tata Power against various criterion listed above. Rekettye, G, \&, Terszty'anszky T.

2. For I26. Interactive customer's service criterion. Reliance Energy showed better performance than MSEDCL, Mumbai, MSEDCL, Pune and BEST.

3. MSEDCL, Pune showed pointwise gaps of $-60.0,-53.3,-53.3,-28.3$ respectively for all criterion. This indicated that MSEDCL, Pune customers were not satisfied with the I26.Interactive customer service,I27.Customer teleservice as highest gaps are noticed against these criterions.

4. For I 28. Communication via the Internet criterion. BEST indicated highest gap of 55.6 points.

5. For I29. Communication via a newsletter criterion, BEST showed highest gap of -55.0 points. 
6. MSEDCL, Mumbai showed pointwise gaps of - 46.7, - 43.3,- 45.0, -26.7 respectively for all criterion.

7. Reliance Energy showed pointwise gaps of $-36.7,-43.3,-45.0,-35.0$ respectively for all criterion.

Table 10. Measures taken by electricity distribution company in detecting \& control of power thefts (The customer responses are given in the following Table 10 and Fig.10)

\begin{tabular}{|c|c|c|c|c|}
\hline Critreion & Company & $\begin{array}{l}\text { Importance } \\
\text { (I) }\end{array}$ & $\begin{array}{c}\text { Satisfaction } \\
\text { (S) }\end{array}$ & Gap $=(S-I)$ \\
\hline \multirow{5}{*}{$\begin{array}{l}\text { J30.Clear case } \\
\text { of power theft. }\end{array}$} & MSEDCL Mumbai & 90.0 & 45.0 & -45.0 \\
\hline & Tata Power & 100.0 & 100.0 & 0.0 \\
\hline & Reliance Energy & 81.7 & 66.7 & -15.0 \\
\hline & BEST & 70.0 & 43.3 & -26.7 \\
\hline & MSEDCL Pune & 91.7 & 36.7 & -55.0 \\
\hline \multirow{5}{*}{$\begin{array}{l}\text { J31. Authorized } \\
\text { connection but } \\
\text { tampered meter }\end{array}$} & MSEDCL Mumbai & 96.7 & 45.0 & -51.7 \\
\hline & Tata Power & 100.0 & 100.0 & 0.0 \\
\hline & Reliance Energy & 81.7 & 61.7 & -20.0 \\
\hline & BEST & 68.3 & 38.3 & -30.0 \\
\hline & MSEDCL Pune & 90.0 & 36.7 & -53.3 \\
\hline \multirow{5}{*}{$\begin{array}{l}\text { J32. Action } \\
\text { taken on power } \\
\text { thefts and } \\
\text { followed } \\
\text { through. }\end{array}$} & MSEDCL Mumbai & 96.7 & 38.3 & -58.4 \\
\hline & Tata Power & 100.0 & 100.0 & 0.0 \\
\hline & Reliance Energy & 81.7 & 61.7 & -20.0 \\
\hline & BEST & 68.3 & 43.3 & -25.0 \\
\hline & MSEDCL Pune & 100.0 & 55.0 & -45.0 \\
\hline
\end{tabular}


Fig.10: Measures taken by electricity distribution company in detecting $\&$ control of power thefts

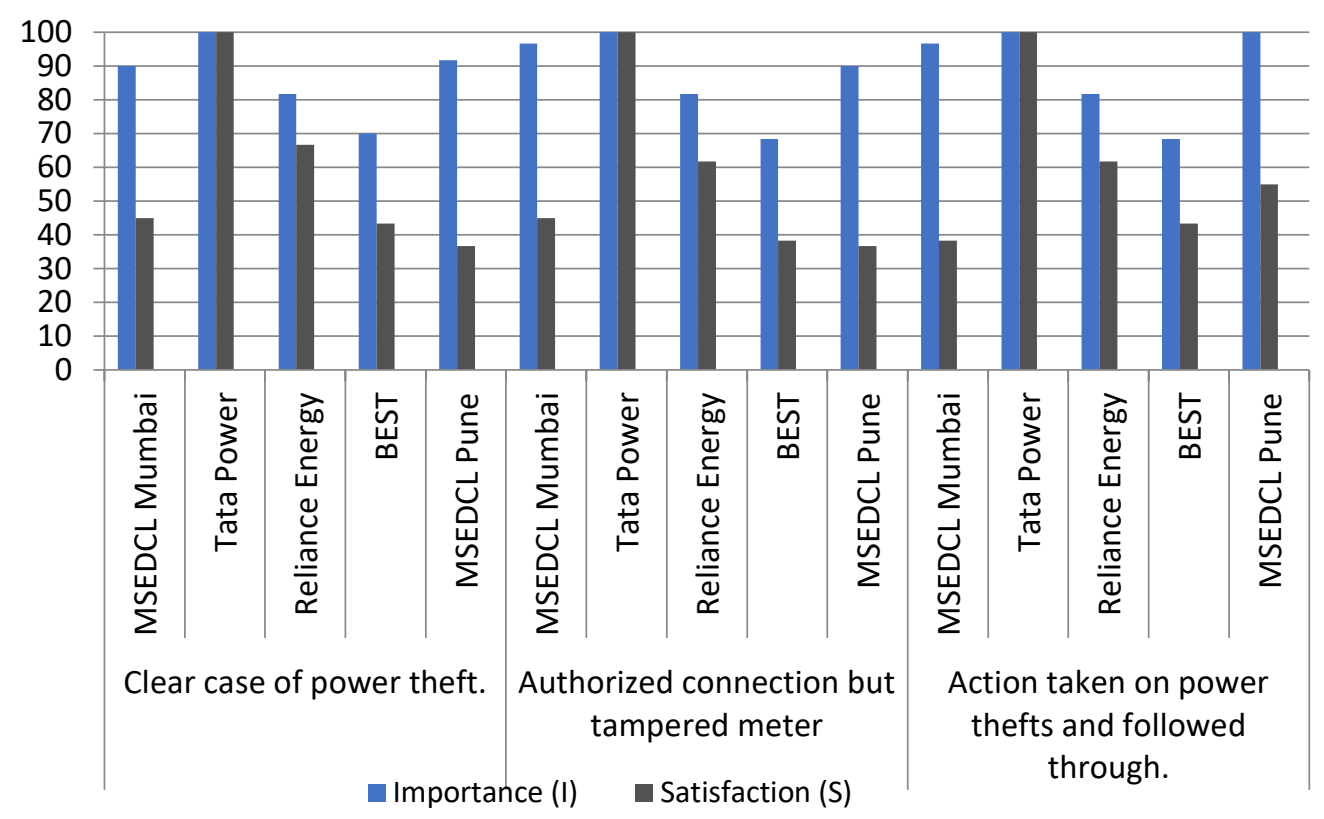

Data analysis of gaps and its interpretation

1. Least pointwise gaps of $0,0,0$ were seen with Tata Power meaning that the customer expectations were met by Tata Power company for all criterion.

2. Reliance Energy(-15.0 points, -20.0 points , -20.0 points) and BEST (-26.7points, -30.0 points, -25.0 points) showed better performance than MSEDCL, Pune and MSEDCL, Mumbai./ MSEDCL, Mumbai and Pune indicated pointwise gaps of -45.0, -51.7, 58.4 and $-55.0,-53.3,-45.0$ for all criterion.

3. MSEDCL, Pune indicated highest gaps for J30. Clear case of power theft and J31.Authorized connection but tampered meter criterion.

4. MSEDCL, Mumbai showed highest gap for J32. Action taken on power theft and followed through criterion

The above results clearly indicated Tata Power as the benchmarked company.

\section{Attribute wise data analysis and its interpretation for domestic customers}

Attribute wise analysis of gaps and its interpretation for domestic customers is given below- 
Table 11. Criticality ef service (The customer responses to criticality of service are given in the following TableFig )

\begin{tabular}{|c|l|l|l|}
\hline \multicolumn{1}{|c|}{ Criteria } & \multicolumn{1}{|c|}{ Company } & \multicolumn{1}{|c|}{$\begin{array}{c}\text { Importance } \\
\text { (I) }\end{array}$} & $\begin{array}{c}\text { Satisfaction } \\
\text { (S) }\end{array}$ \\
\hline \multirow{4}{*}{$\begin{array}{c}\text { A1. Uninterrupted } \\
\text { power supply }\end{array}$} & MSEDCL, Mumbai & 100.0 & 53.3 \\
& Tata Power & 100.0 & 98.3 \\
& Reliance Energy & 100.0 & 73.3 \\
& BEST & 100.0 & 85.0 \\
& MSEDCL Pune & 100.0 & 26.7 \\
\hline \multirow{4}{*}{ A2. Speed of restoration } & MSEDCL Mumbai & 100.0 & 56.7 \\
& Tata Power & 100.0 & 100.0 \\
& Reliance Energy & 100.0 & 70.0 \\
& BEST & 100.0 & 78.3 \\
& MSEDCL Pune & 100.0 & 31.7 \\
\hline \multirow{3}{*}{ A3. Minimal voltage } & MSEDCL Mumbai & 100.0 & 43.3 \\
fluctuations & Tata Power & 100.0 & 100.0 \\
& Reliance Energy & 100.0 & 75.0 \\
& BEST & 98.3 & 86.7 \\
& MSEDCL Pune & 100.0 & 26.7 \\
\hline
\end{tabular}

This attribute is decided on the following three criterions

- A1. Uninterrupted power supply.

- A2. Speed of restoration of power supply.

- A3. Minimal voltage fluctuations. 


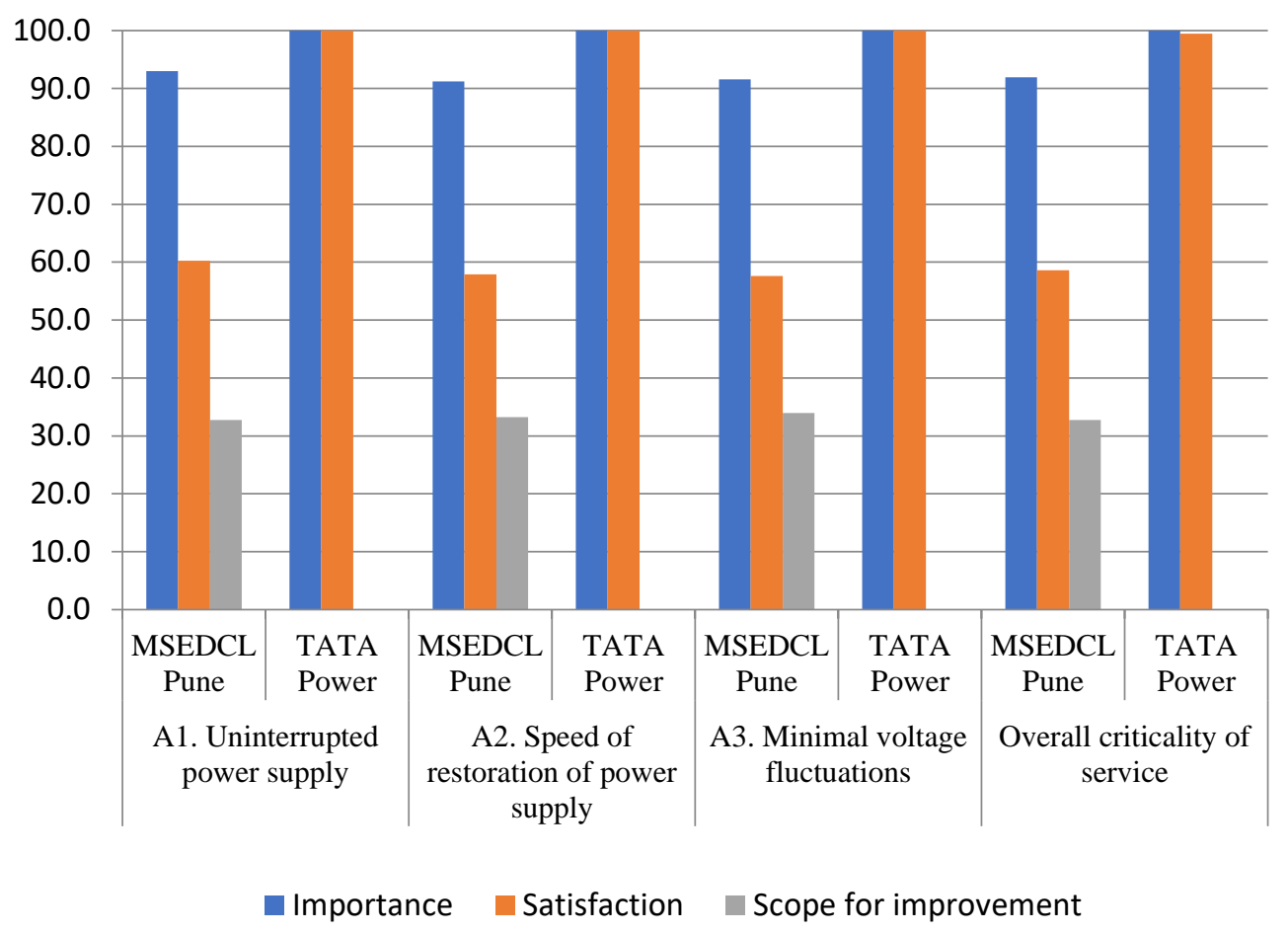

Fig.11: Criticality of service

1. All three criterion required almost equal emphasis.

1. 2. A gap of -32.8 points was noticed for $\mathrm{A} 1$, uninterrupted power supply criterion in case of MSEDCL, Pune. The scope for improvements therefore was 31.1 points as the gap of Tata Power was -1.7 points.

2. 3. For speed of restoration criterion, A2, the gap observed was-33.3 points in case of MSEDCL Pune and therefore the scope for improvements was 33.3 points as Tata Power the gap of 0 points.

3. For minimal voltage fluctuations criterion, A3, the gap noticed was $-33.9 \& 0$ points in case of MSEDCL, Pune \& Tata Power respectively leaving scope for improvement of 33.9 points.

4. Overall for this attribute the scope for improvement is 32.7 points.

Table 12. Consumer's safety (The customer responses for consumer's safety details are given in following Table. 2)

\begin{tabular}{|c|l|c|c|c|c|}
\hline \multicolumn{1}{|c|}{ Criterion } & $\begin{array}{c}\text { Electricity distribution } \\
\text { company }\end{array}$ & Importance ( I) & Satisfaction ( S) & Gap=(S-I) & $\begin{array}{c}\text { Scope for } \\
\text { improvement }\end{array}$ \\
\hline $\begin{array}{l}\text { B4 Focus on } \\
\text { safety }\end{array}$ & MSEDCL Pune & 90.15 & 61.93 & -28.2 & 26.5 \\
& Tata Power & 100.00 & 98.3 & -1.7 & \\
\hline
\end{tabular}




\section{Findings}

The gap of -28.2 points and -1.7 points was noticed in case of MSEDCL and Tata Power respectively for this criterion. The scope for improvement therefore was 26.5 points for consumer's safety criterion.

Table 13. Complaint handling system(connectivity). The responses from customers for complaint handling system were as given in Table e 16and Fig. below

\begin{tabular}{|c|c|c|c|c|c|}
\hline Criterion & $\begin{array}{c}\text { Electricity } \\
\text { Distribution } \\
\text { company }\end{array}$ & $\begin{array}{c}\text { Importance } \\
\text { (I) }\end{array}$ & $\begin{array}{c}\text { Satisfaction } \\
\text { (S) }\end{array}$ & $\begin{array}{c}\text { Gap } \\
=(\mathbf{S}-\mathbf{I})\end{array}$ & $\begin{array}{c}\text { Scope for } \\
\text { improvement }\end{array}$ \\
\hline $\begin{array}{c}\text { C5. Response to } \\
\text { customer need }\end{array}$ & $\begin{array}{c}\text { MSEDCL Pune } \\
\text { Tata Power }\end{array}$ & $\begin{array}{c}90.2 \\
100.0\end{array}$ & $\begin{array}{c}55.9 \\
93.3\end{array}$ & $\begin{array}{c}-34.3 \\
-6.7\end{array}$ & 27.6 \\
\hline $\begin{array}{c}\text { C6. Timely fault } \\
\text { attending }\end{array}$ & $\begin{array}{c}\text { MSEDCL Pune } \\
\text { Tata Power }\end{array}$ & 90.8 & 55.7 & -35.1 & 28.4 \\
\hline $\begin{array}{c}\text { C7. Time taken } \\
\text { for } \\
\text { administrative } \\
\text { procedures }\end{array}$ & MSEDCL Pune & 81.1 & 53.0 & -28.1 & 26.4 \\
\hline $\begin{array}{c}\text { C8. in number of } \\
\text { receiving points }\end{array}$ & MSEDCL Pune & 76.9 & 53.6 & -23.3 & 18.3 \\
\hline $\begin{array}{c}\text { C9. Speed at } \\
\text { Thich consumer } \\
\text { grievance related } \\
\text { issues are } \\
\text { handled }\end{array}$ & MSEDCL Pune & 86.7 & 51.9 & -34.8 & 26.5 \\
\hline $\begin{array}{c}\text { Overall } \\
\text { complaint } \\
\text { handling system }\end{array}$ & Mata Power & 98.3 & 90.0 & -8.3 & \\
\hline \multicolumn{2}{|c|}{ Tata Power } & 95.3 & 89.7 & -5.7 & 25.7 \\
\hline
\end{tabular}


Fig.12: Complaint handling system(connectivity)

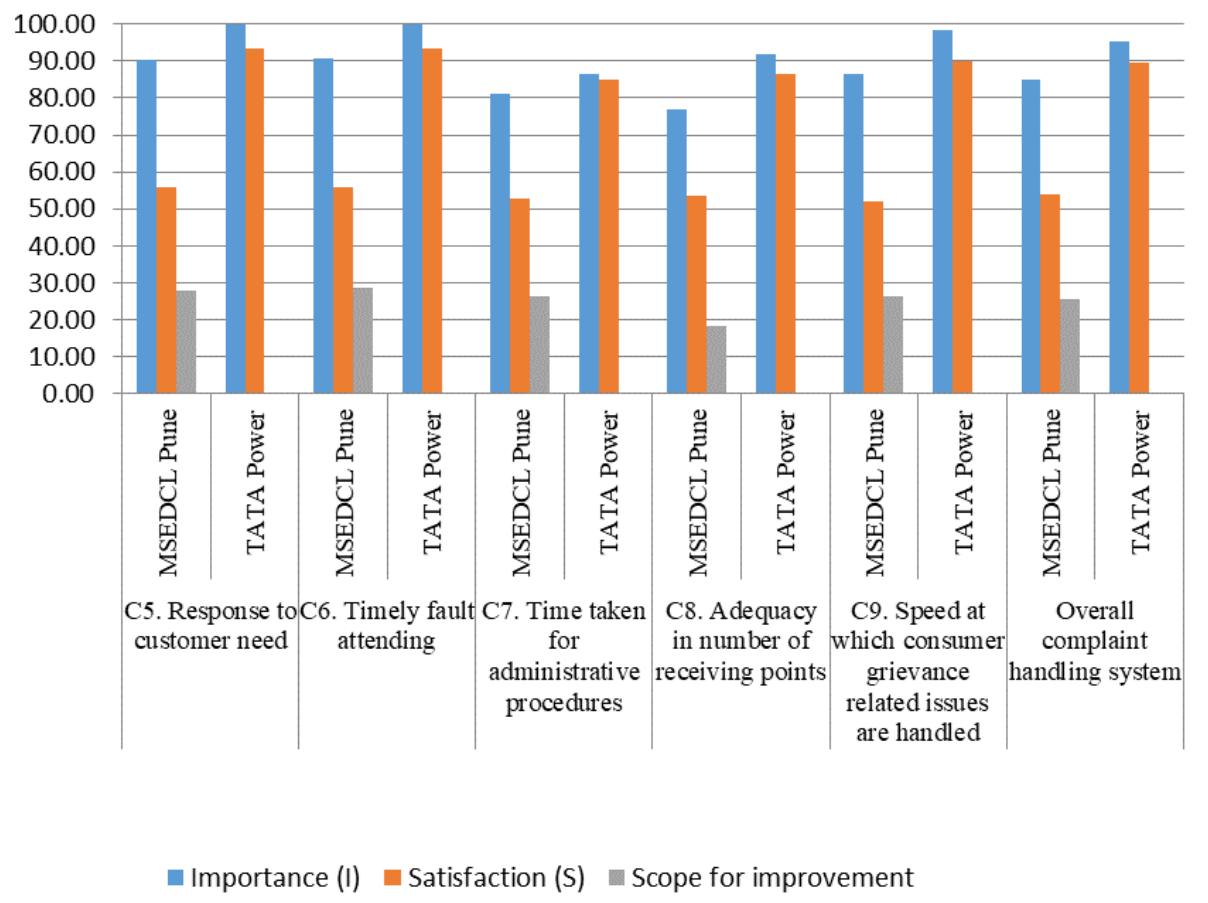

\section{Findings}

1. C5, response to customer need criterion for MSEDCL. For the same criterion, a gap of -6.7 was observed for Tata Power . The scope for improvement therefore was 27.6 points.

2. For,C6, timely fault attending criterion , the gap was -35.1 and -6.7 for MSEDCL and Tata Power respectively. The scope for improvement was 28.4 points.

3. For, $\mathrm{C} 7$, time taken for administrative procedures criterion, the point wise gap noticed was -28.1 and -1.7 of MSEDCL and Tata Power respectively. The scope for improvement was 26.4 points.

4. The MSEDCL consumers in Pune were relatively satisfied with C8.Adequacy in number of receiving point's criterion. The gap observed is -23.3 points and -5.0 points for MSEDCL and Tata Power respectively for this criterion. The scope for improvement was 18.3 points.

5. For ,C 9 ,criterion of speed at which consumer grievance related issues were handled, the observed point wise gap was -34.8 and -8.3 for MSEDCL and Tata Power respectively. The scope for improvement was 26.5 points.

6. Finally, overall for this attribute the scope for improvement was 25.5 points. 
Table 13. Reliability of supply / service. The customer responses for reliability of supply / service are given in the following Table

\begin{tabular}{|c|c|c|c|c|c|}
\hline Criterion & $\begin{array}{c}\text { Electricity } \\
\text { distribution } \\
\text { company }\end{array}$ & $\begin{array}{c}\text { Importance } \\
(\mathbf{I})\end{array}$ & $\begin{array}{c}\text { Satisfaction } \\
\text { (S) }\end{array}$ & $\begin{array}{c}\text { Gap= } \\
\text { (S-I) }\end{array}$ & $\begin{array}{c}\text { Scope for } \\
\text { improvement }\end{array}$ \\
\hline $\begin{array}{c}\text { D10. } \\
\text { Continuity of } \\
\text { power supply }\end{array}$ & MSEDCL Pune & 87.9 & 49.6 & -38.3 & 36.6 \\
\hline
\end{tabular}

\section{Findings}

The observed point wise gaps for this attribute were -38.3 and -1.7 for MSEDCL and Tata Power respectively. The scope for improvement therefore was 36.6 points.

Table 14. Quality of supply/ service. The customer responses for quality of supply/ service are

\begin{tabular}{|c|c|c|c|c|c|}
\hline Criterion & $\begin{array}{l}\text { Electricity } \\
\text { distribution } \\
\text { company }\end{array}$ & $\begin{array}{l}\text { Importance } \\
\text { (I) }\end{array}$ & $\begin{array}{l}\text { Satisfaction } \\
\text { (S) }\end{array}$ & $\begin{array}{l}\text { Gap= } \\
(\text { S-I })\end{array}$ & $\begin{array}{l}\text { Scope for } \\
\text { improvement }\end{array}$ \\
\hline $\begin{array}{l}\text { E11. } \\
\text { Availability of } \\
\text { smooth power } \\
\text { supply }\end{array}$ & $\begin{array}{l}\text { MSEDCL Pune } \\
\text { Tata Power }\end{array}$ & $\begin{array}{l}89.0 \\
98.3\end{array}$ & $\begin{array}{l}53.6 \\
100.0\end{array}$ & $\begin{array}{l}-35.3 \\
1.7\end{array}$ & 37.0 \\
\hline $\begin{array}{l}\text { E12. } \\
\text { Exactness of } \\
\text { work by } \\
\text { Electricity } \\
\text { Distribution } \\
\text { Company } \\
\text { employee }\end{array}$ & $\begin{array}{l}\text { MSEDCL Pune } \\
\text { Tata Power }\end{array}$ & $\begin{array}{l}87.4 \\
98.3\end{array}$ & $\begin{array}{l}62.4 \\
96.7\end{array}$ & $\begin{array}{l}-25.0 \\
-1.7\end{array}$ & 23.3 \\
\hline $\begin{array}{l}\text { E13. } \\
\text { Compliance to } \\
\text { safety norms } \\
\text { by Electricity } \\
\text { Distribution } \\
\text { Company } \\
\text { employee }\end{array}$ & $\begin{array}{l}\text { MSEDCL Pune } \\
\text { Tata Power }\end{array}$ & $\begin{array}{l}88.3 \\
98.3\end{array}$ & $\begin{array}{l}61.5 \\
96.7\end{array}$ & $\begin{array}{l}-26.8 \\
-1.7\end{array}$ & 25.1 \\
\hline $\begin{array}{l}\text { Overall } \\
\text { quality of } \\
\text { supply }\end{array}$ & $\begin{array}{l}\text { MSEDCL Pune } \\
\text { Tata Power }\end{array}$ & $\begin{array}{l}88.2 \\
98.3\end{array}$ & $\begin{array}{l}59.2 \\
-0.6\end{array}$ & -29.1 & 28.5 \\
\hline
\end{tabular}




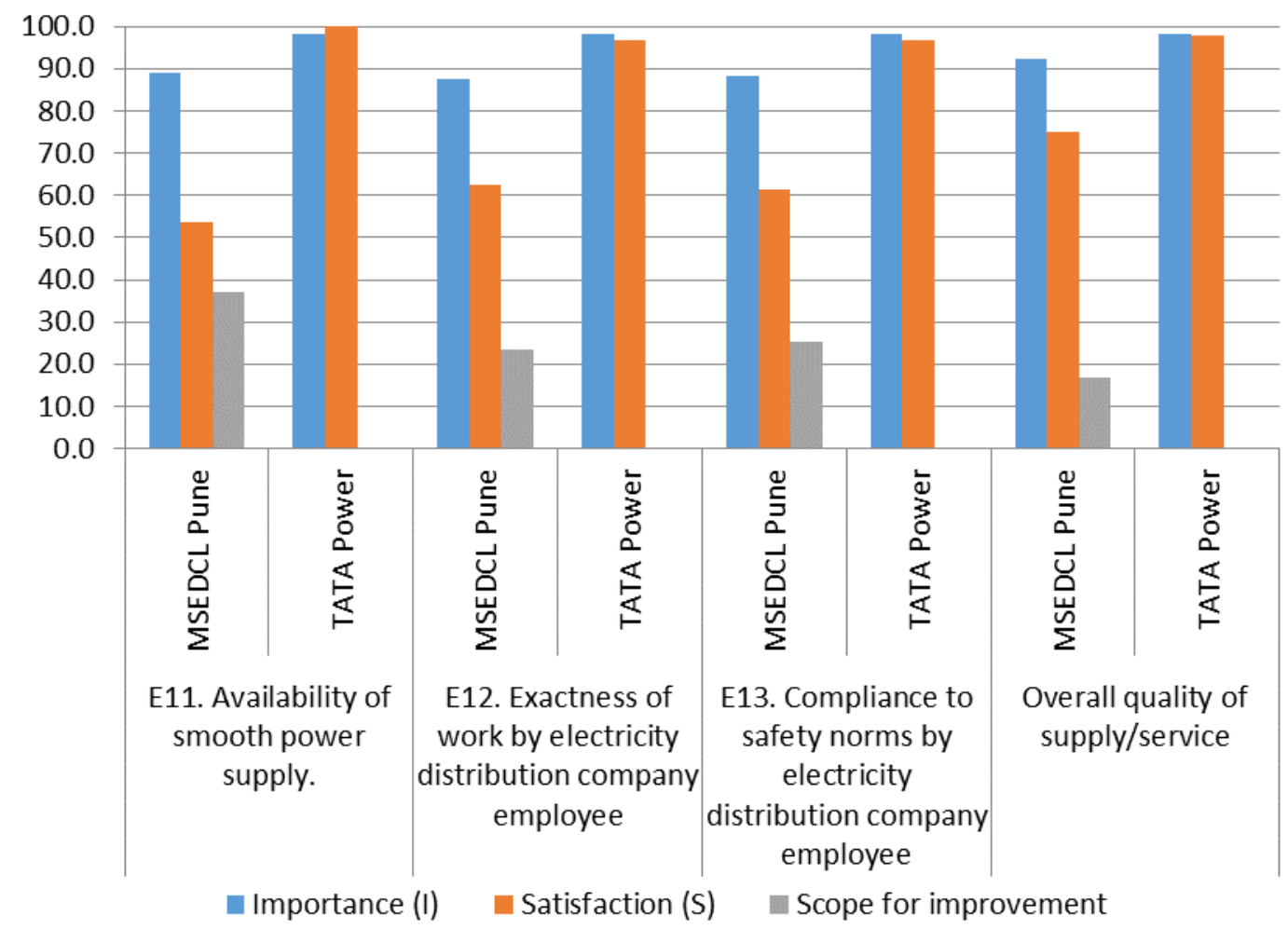

Fig.14: Quality of supply/ service

\section{Findings}

1. Maximum gap of -35.3 points was noticed in case of E11, availability of smooth power supply for MSEDCL. For the same criterion, a gap of 1.7 points was noticed in case of Tata Power indicating over performance and customer delight. The scope for improvement therefore was 37.0 points.

2. The gap of -25.0 points was observed for E12, exactness of work done by electricity distribution company employee in case of MSEDCL, Pune. Since the observed gap was -1.7 points in case of Tata Power, the scope for improvement is 23.3 points for this criterion.

3. For E13, compliance to safety norms by electricity distribution company employee criterion, a gap -26.8 points was noticed in case of MSEDCL, Pune. The scope for improvement is 25.1 points as a gap of -1.7 points was noticed for Tata Power and for the overall attribute was 28.5 points. 
Table 15. Accurate and punctual meter reading. The customer responses for accurate and punctual meter reading are as given in the following

\begin{tabular}{|c|c|c|c|c|c|}
\hline Criterion & $\begin{array}{l}\text { Electricity } \\
\text { distribution } \\
\text { company }\end{array}$ & $\begin{array}{l}\text { Importance } \\
\text { (I) }\end{array}$ & $\begin{array}{l}\text { Satisfaction } \\
\text { (S) }\end{array}$ & $\begin{array}{l}\text { Gap= } \\
(\text { S-I })\end{array}$ & $\begin{array}{l}\text { Scope for } \\
\text { improvement }\end{array}$ \\
\hline $\begin{array}{l}\text { F14. Frequency } \\
\text { of meter reading. }\end{array}$ & $\begin{array}{l}\text { MSEDCL Pune } \\
\text { Tata Power }\end{array}$ & $\begin{array}{l}89.3 \\
95.0\end{array}$ & $\begin{array}{l}58.4 \\
90.0\end{array}$ & $\begin{array}{l}-30.9 \\
-5.0\end{array}$ & 25.9 \\
\hline $\begin{array}{l}\text { F15. Specific } \\
\text { date of meter } \\
\text { reading. }\end{array}$ & $\begin{array}{l}\text { MSEDCL Pune } \\
\text { Tata Power }\end{array}$ & $\begin{array}{l}83.5 \\
93.3\end{array}$ & $\begin{array}{l}54.2 \\
86.7\end{array}$ & $\begin{array}{l}-29.3 \\
-6.6\end{array}$ & 22.6 \\
\hline $\begin{array}{lr}\text { F.16 Reliability } \\
\text { of } \\
\text { reading }\end{array}$ & $\begin{array}{l}\text { MSEDCL Pune } \\
\text { Tata Power }\end{array}$ & $\begin{array}{l}89.0 \\
100.0\end{array}$ & $\begin{array}{l}68.4 \\
100.0\end{array}$ & $\begin{array}{l}-20.6 \\
0.0\end{array}$ & 20.6 \\
\hline $\begin{array}{l}\text { Overall Accurate } \\
\text { and Punctual } \\
\text { meter reading }\end{array}$ & $\begin{array}{l}\text { MSEDCL Pune } \\
\text { Tata Power }\end{array}$ & $\begin{array}{l}87.3 \\
96.1\end{array}$ & $\begin{array}{l}60.3 \\
92.2\end{array}$ & $\begin{array}{l}-27.0 \\
-3.9\end{array}$ & 23.1 \\
\hline
\end{tabular}

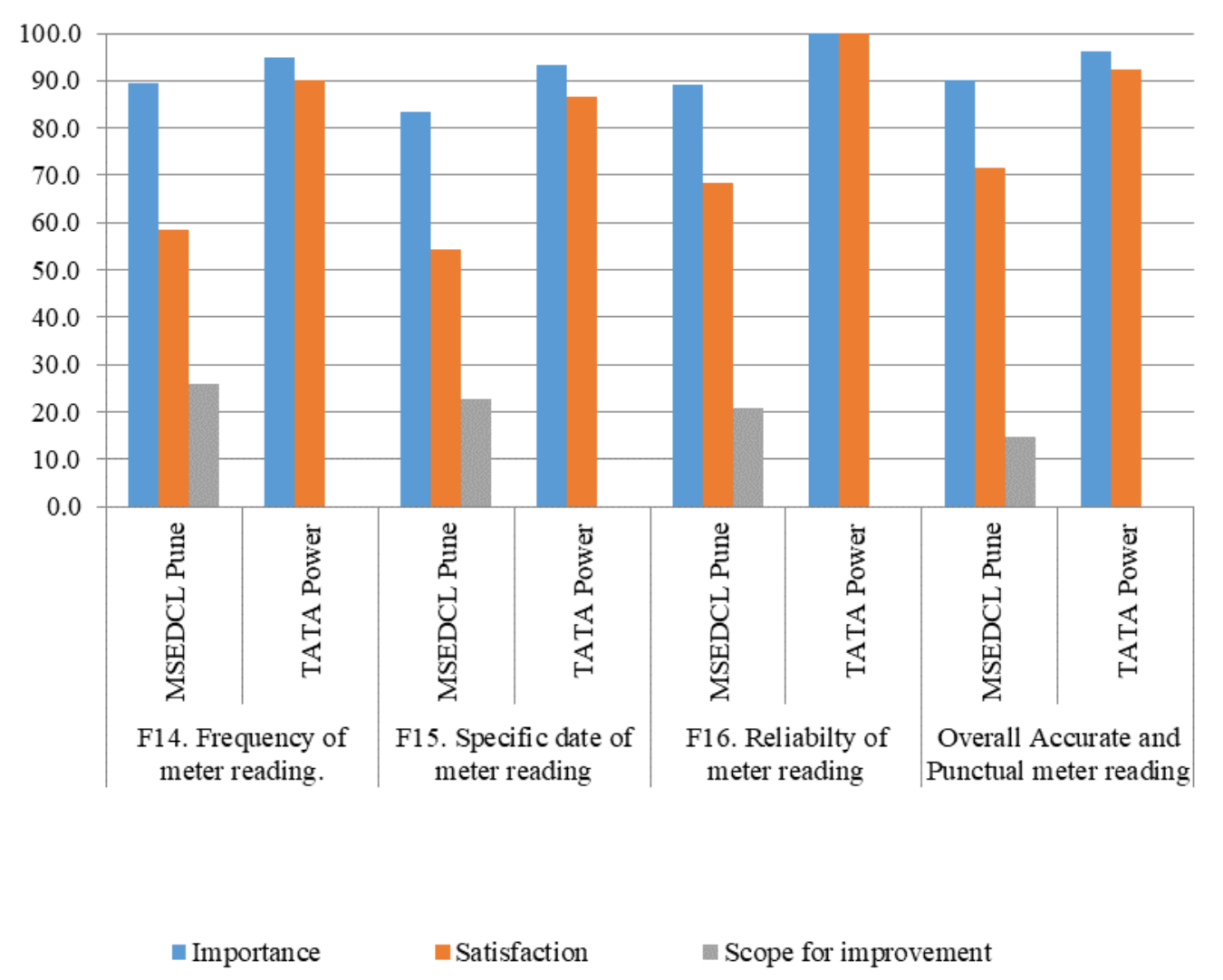

Fig. 15: Accurate and punctual meter reading 


\section{Findings}

1. For F14, frequency of meter reading, the MSEDCL customers were least satisfied as it was evident from maximum gap of -30.9 points against a gap of -5.0 points for Tata Power. There was a maximum scope for improvement of 25.9 points for this criterion.

2. F15, specific date of meter reading criterion, the point wise gap was -29.3 and -6.7 for MSEDCL and Tata Power respectively. Hence the scope for improvement was 22.6 points.

3. For F16, reliability of meter reading criterion results indicates that MSEDCL customers are relatively satisfied as seen from least gap of -20.6 points. As Tata Power showed zero gaps, the scope for improvement was 20.6 points. The overall scope for these attributes was 23.1 points

Table 16. Accuracy \& reliability of billing

\begin{tabular}{|c|c|c|c|c|c|}
\hline Criterion & $\begin{array}{l}\text { Electricity } \\
\text { distribution } \\
\text { company }\end{array}$ & $\begin{array}{l}\text { Importance } \\
\text { (I) }\end{array}$ & $\begin{array}{l}\text { Satisfaction } \\
\text { (S) }\end{array}$ & $\begin{array}{l}\text { Gap= } \\
(\text { S-I })\end{array}$ & $\begin{array}{l}\text { Scope for } \\
\text { improvement }\end{array}$ \\
\hline $\begin{array}{l}\text { G17.Clarity on } \\
\text { details of bill. }\end{array}$ & $\begin{array}{l}\text { MSEDCL Pune } \\
\text { Tata Power }\end{array}$ & $\begin{array}{l}91.9 \\
100.0\end{array}$ & $\begin{array}{l}57.8 \\
96.7\end{array}$ & $\begin{array}{l}-34.1 \\
-3.3\end{array}$ & 30.8 \\
\hline $\begin{array}{l}\text { G18. } \\
\text { Conformity of } \\
\text { bill to the } \\
\text { consumption }\end{array}$ & $\begin{array}{l}\text { MSEDCL Pune } \\
\text { Tata Power }\end{array}$ & $\begin{array}{l}89.7 \\
100.0\end{array}$ & $\begin{array}{l}67.2 \\
100.0\end{array}$ & $\begin{array}{l}-22.5 \\
0.0\end{array}$ & 22.5 \\
\hline $\begin{array}{l}\text { G19. Bill } \\
\text { distribution at } \\
\text { delivery point }\end{array}$ & $\begin{array}{l}\text { MSEDCL Pune } \\
\text { Tata Power }\end{array}$ & $\begin{array}{l}87.1 \\
100.0\end{array}$ & $\begin{array}{l}57.4 \\
96.7\end{array}$ & $\begin{array}{l}-29.7 \\
-3.3\end{array}$ & 26.4 \\
\hline $\begin{array}{lr}\text { G20. Bill not } \\
\text { received } \\
\text { weeks } \\
\text { due date }\end{array}$ & $\begin{array}{l}\text { MSEDCL Pune } \\
\text { Tata Power }\end{array}$ & $\begin{array}{l}84.8 \\
100.0\end{array}$ & $\begin{array}{l}50.1 \\
98.3\end{array}$ & $\begin{array}{l}-34.7 \\
-1.7\end{array}$ & 33.1 \\
\hline $\begin{array}{l}\text { G21. Response } \\
\text { on incorrect bill. }\end{array}$ & $\begin{array}{l}\text { MSEDCL Pune } \\
\text { Tata Power }\end{array}$ & $\begin{array}{l}86.3 \\
100.0\end{array}$ & $\begin{array}{l}50.0 \\
96.0\end{array}$ & $\begin{array}{l}-36.3 \\
-4.0\end{array}$ & 32.3 \\
\hline $\begin{array}{l}\text { G22. Speed at } \\
\text { which duplicate } \\
\text { bill is issued }\end{array}$ & $\begin{array}{l}\text { MSEDCL Pune } \\
\text { Tata Power }\end{array}$ & $\begin{array}{l}85.7 \\
100.0\end{array}$ & $\begin{array}{l}52.4 \\
93.3\end{array}$ & $\begin{array}{l}-33.3 \\
-6.7\end{array}$ & 26.6 \\
\hline $\begin{array}{l}\text { G23.Time lag } \\
\text { for reconnection } \\
\text { after the } \\
\text { payment }\end{array}$ & $\begin{array}{l}\text { MSEDCL Pune } \\
\text { Tata Power }\end{array}$ & $\begin{array}{l}86.8 \\
100.0\end{array}$ & $\begin{array}{l}51.9 \\
100.0\end{array}$ & $\begin{array}{l}-34.9 \\
0.0\end{array}$ & 34.9 \\
\hline $\begin{array}{l}\text { G24. Reliability } \\
\text { of electronic } \\
\text { clearing system }\end{array}$ & $\begin{array}{l}\text { MSEDCL Pune } \\
\text { Tata Power }\end{array}$ & $\begin{array}{l}88.0 \\
98.2\end{array}$ & $\begin{array}{l}66.1 \\
98.2\end{array}$ & $\begin{array}{l}-21.9 \\
0.0\end{array}$ & 21.9 \\
\hline $\begin{array}{ll}\text { Overall } & \\
\text { Accuracy } & \& \\
\text { Reliability } & \text { of } \\
\text { Billing } & \end{array}$ & $\begin{array}{l}\text { MSEDCL Pune } \\
\text { Tata Power }\end{array}$ & $\begin{array}{l}87.5 \\
99.8\end{array}$ & $\begin{array}{l}56.6 \\
97.4\end{array}$ & $\begin{array}{l}-30.9 \\
-2.4\end{array}$ & 28.5 \\
\hline
\end{tabular}




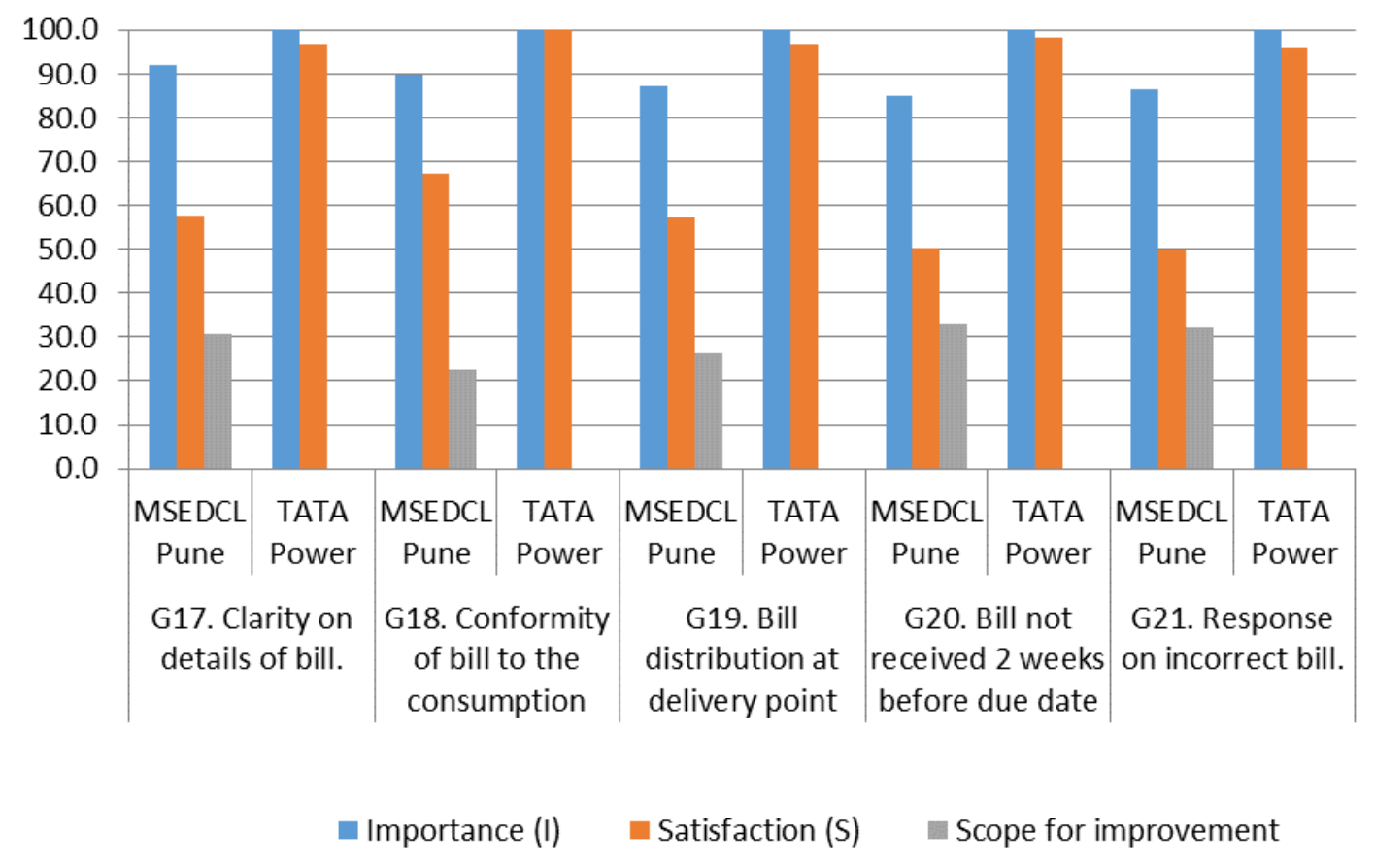

Fig. 15 Accuracy \& reliability of billing

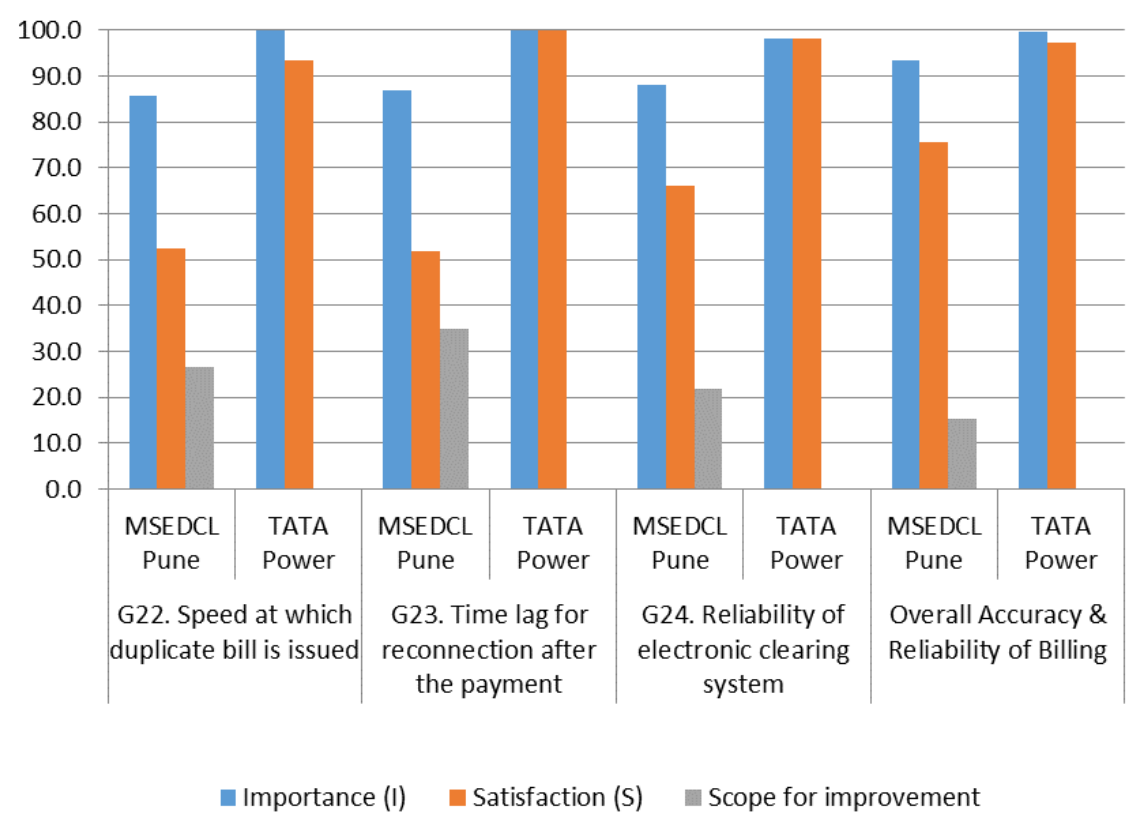

Fig16: Accuracy \& reliability of billing 


\section{Findings}

1. For MSEDCL, a gap of -34.9 points was observed for G23, time lag for reconnection after payments. The scope for improvement is 34.9 points as there was 0 points gap noticed for Tata Power.

2. For MSEDCL, a gap of - 34.7 points was noticed for G20, not received 2 weeks before due date criterion. The scope for improvement was 33.1 points as there was a gap of 1.7 points noticed in case of Tata Power.

3. A gap of -36.3 points is noticed in $\mathrm{G} 21$, response on incorrect bill criterion for MSEDCL. The scope for improvement is 32.3 points due to gap of -4.0 points in case of Tata Power.

4. A gap of- 34.1 points was observed for G17, clarity on bills details criterion for MSEDCL. The scope for improvement therefore is 30.8 points due to gap of -3.3 points for Tata Power.

5. A gap of -29.7 points was noticed for $\mathrm{G} 19$, bill distribution at delivery point's criterion for MSEDCL. The scope for improvement is 26.4 points as Tata Power indicated a gap of -3.3 points.

6. A gap of -21.9 points was observed for $\mathrm{G} 24$, reliability of electronic clearing system criterion for MSEDCL. The scope for improvement therefore was 21.9 points as 0 points gap is noticed in case of Tata Power.

7. A gap of -22.5 points was observed in case of G18, conformity of bill consumption criterion for MSEDCL. Introduction of photo meter reading has assisted MSEDCL, Pune in reducing gaps. The scope for improvement is 22.5 points as 0 points gap was noticed in case of Tata Power. However ,the photometer readings were an outsourced activity and it defeated the very purpose as the photometer readings were not readable.

8. For G22, speed at which duplicate bill is issued criterion, observed gap was -33.3 points for MSEDCL. A gap of -6.7 points is noticed in case of Tata Power. The scope for improvement therefore was 26.6 points. The overall scope for this attribute was 28.5 points'

Table 17. Power tariff (The customer responses for power tariff are as given in the following Table 18 below)

\begin{tabular}{|l|l|l|l|l|l|}
\hline Criterion & $\begin{array}{l}\text { Electricity } \\
\text { distribution } \\
\text { company }\end{array}$ & $\begin{array}{l}\text { Importance } \\
\text { (I) }\end{array}$ & $\begin{array}{l}\text { Satisfaction } \\
\text { (S) }\end{array}$ & $\begin{array}{l}\text { Gap } \\
=(\mathbf{S}-\mathbf{I})\end{array}$ & $\begin{array}{l}\text { Scope for } \\
\text { improvement }\end{array}$ \\
\hline $\begin{array}{l}\text { H25. Present } \\
\text { Power Tariff }\end{array}$ & MSEDCL Pune & 88.9 & 45.8 & -43.1 & 43.1 \\
Tata Power & 98.2 & 98.2 & 0.0 & \\
\hline
\end{tabular}

\section{Findings}

1 Tata Power customers were fully satisfied with power tariff as there were zero points gaps observed. The scope for improvement was 43.1 points. 
Table 18. Awareness of price revision. The customer's responses to awareness of price revision are given in the following Table 19

\begin{tabular}{|l|l|}
\hline Response & Count \\
\hline a. Yes & 186 \\
\hline b. No & 84 \\
\hline Total & 270 \\
\hline
\end{tabular}

\section{Findings}

a) Majority of MSEDCL's domestic customers were aware of revision in power tariff.

b) This awareness was due to the fact that many newspapers published reports in this regard.

Table 19. Interaction with customer. The customer responses for interaction with customer attribute are given in Table 20 and Fig 17 below

\begin{tabular}{|c|c|c|c|c|c|}
\hline Criterion & $\begin{array}{l}\text { Electricity } \\
\text { distribution } \\
\text { company }\end{array}$ & $\begin{array}{l}\text { Importance } \\
\text { (I) }\end{array}$ & $\begin{array}{l}\text { Satisfaction } \\
\text { (S) }\end{array}$ & $\begin{array}{l}\text { Gap= } \\
(\mathrm{S}-\mathrm{I})\end{array}$ & $\begin{array}{l}\text { Scope for } \\
\text { improvement }\end{array}$ \\
\hline $\begin{array}{l}\text { I27. Interactive } \\
\text { customer's service }\end{array}$ & $\begin{array}{l}\text { MSEDCL Pune } \\
\text { Tata Power }\end{array}$ & $\begin{array}{l}84.6 \\
100.0\end{array}$ & $\begin{array}{l}49.9 \\
98.3\end{array}$ & $\begin{array}{r}-34.7 \\
-1.7\end{array}$ & 33.0 \\
\hline $\begin{array}{l}\text { I28. Customer } \\
\text { telephonic service }\end{array}$ & $\begin{array}{l}\text { MSEDCL Pune } \\
\text { Tata Power }\end{array}$ & $\begin{array}{l}78.8 \\
96.7\end{array}$ & $\begin{array}{l}42.3 \\
93.4\end{array}$ & $\begin{array}{r}-36.5 \\
-3.3 \\
\end{array}$ & 33.2 \\
\hline $\begin{array}{l}\text { I } 29 . \\
\text { Communication } \\
\text { via the Internet }\end{array}$ & $\begin{array}{l}\text { MSEDCL Pune } \\
\text { Tata Power }\end{array}$ & $\begin{array}{l}76.1 \\
100.0\end{array}$ & $\begin{array}{l}49.8 \\
98.3\end{array}$ & $\begin{array}{l}-26.3 \\
1.7\end{array}$ & 24.6 \\
\hline $\begin{array}{l}\text { I30. } \\
\text { Communication } \\
\text { via a newsletter }\end{array}$ & $\begin{array}{l}\text { MSEDCL Pune } \\
\text { Tata Power }\end{array}$ & $\begin{array}{l}59.6 \\
100.0 \\
\end{array}$ & $\begin{array}{l}36.6 \\
100.0 \\
\end{array}$ & $\begin{array}{c}-23.0 \\
0 \\
\end{array}$ & 23.0 \\
\hline $\begin{array}{l}\text { Overall Interaction } \\
\text { with customers }\end{array}$ & $\begin{array}{l}\text { MSEDCL Pune } \\
\text { Tata Power }\end{array}$ & $\begin{array}{l}74.8 \\
99.2\end{array}$ & $\begin{array}{l}46.3 \\
97.5\end{array}$ & $\begin{array}{l}-28.5 \\
-1.7\end{array}$ & 26.8 \\
\hline
\end{tabular}




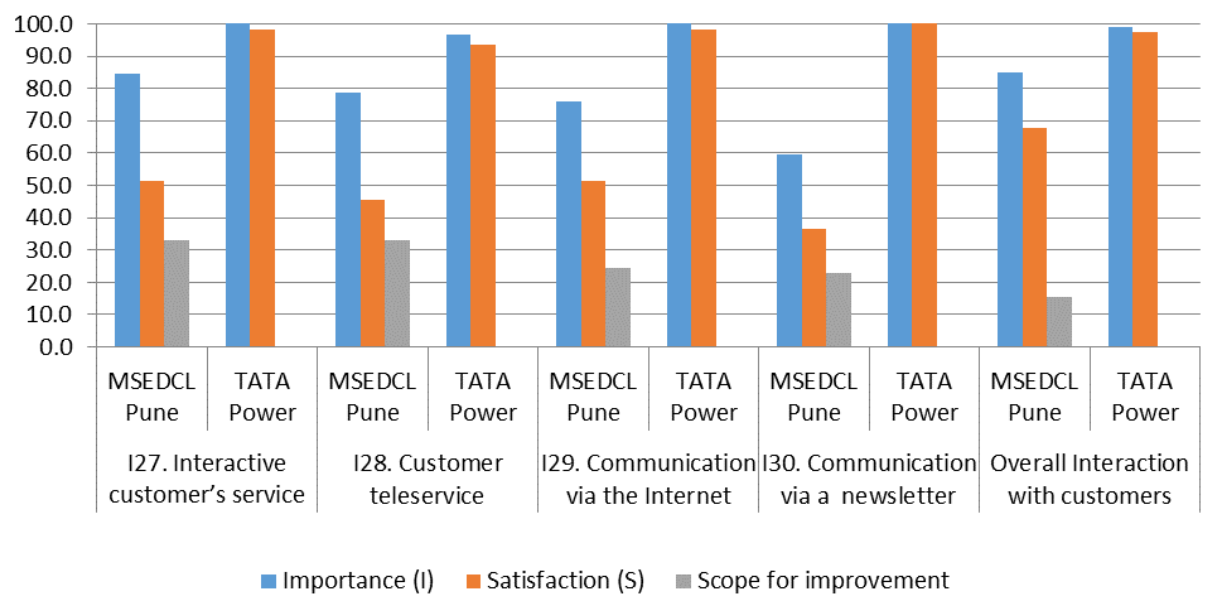

Fig.19. Interaction with customer

\section{Findings}

1. Communication via a newsletter, I30 and communications via the internet, I29, indicated a much better performance than other criterion for this attribute in case of MSEDCL. A gap of -23.0 points and -26. 3 points was observed in case of communication via a newsletter, I30 and communication via the internet, I29, criterion in case of MSEDCL. A gap of - 1.7 points and 0 points is noticed in case of Tata Power for I29 and I30 criterion.

2. For MSEDCL, the scope for improvement is 23.0 points was case of I30, communication via a newsletter.

3. For MSEDCL, the scope for improvement is 24.6 points in case of $\mathbf{I} 29$ communication via the internet.

4. For two other criterion namely interactive customer's service, I27 and customer telephonic service, I28, the gaps observed are-34.7 points and -36.5 points respectively indicating more tension to customers in case of MSEDCL.

5. For MSEDCL, the scope for improvements is 33.0 points as -1.7 points gap was noticed in case of Tata Power in case of I27, interactive customer's service.

6. For MSEDCL, the scope for improvement is 33.2 as -3.3 points gap was noticed in case of Tata Power for I28, customer tale service criterion 
Table 20. Measures taken by electricity distribution company in detecting \& control of power thefts. The following Table 21 and Fig 18 gives customer responses for measures taken by

MSEDCL in detecting \& control of power thefts attribute

\begin{tabular}{|l|l|l|l|l|l|}
\hline Criterion & $\begin{array}{l}\text { Electricity } \\
\text { distribution company }\end{array}$ & $\begin{array}{l}\text { Importance } \\
(\mathrm{I})\end{array}$ & $\begin{array}{l}\text { Satisfaction } \\
(\mathrm{S})\end{array}$ & $\begin{array}{l}\text { Gap= } \\
\text { (S-I) }\end{array}$ & $\begin{array}{l}\text { Scope } \\
\text { improvement }\end{array}$ \\
\hline $\begin{array}{l}\text { J31. Clear case of } \\
\text { power theft }\end{array}$ & $\begin{array}{l}\text { MSEDCL Pune } \\
\text { Tata Power }\end{array}$ & $\begin{array}{l}90.6 \\
100.0\end{array}$ & $\begin{array}{l}51.7 \\
100.0\end{array}$ & -38.9 & 38.9 \\
\hline $\begin{array}{l}\text { J32. Authorized } \\
\text { connection but } \\
\text { tampered meter }\end{array}$ & MSEDCL Pune & 90.3 & 52.8 & -37.5 & 37.5 \\
\hline $\begin{array}{l}\text { J33. Action taken } \\
\text { on power thefts } \\
\text { and followed } \\
\text { through Power }\end{array}$ & MSEDCL Pune & 100.0 & 100.0 & 0.0 & \\
\hline $\begin{array}{l}\text { Overall measures } \\
\text { taken by } \\
\text { electricity } \\
\text { distribution } \\
\text { company in } \\
\text { detecting } \\
\begin{array}{l}\text { control of power } \\
\text { theft }\end{array}\end{array}$ & MSEDCL Pune & 99.9 & 47.9 & -42.0 & 42.0 \\
\hline
\end{tabular}

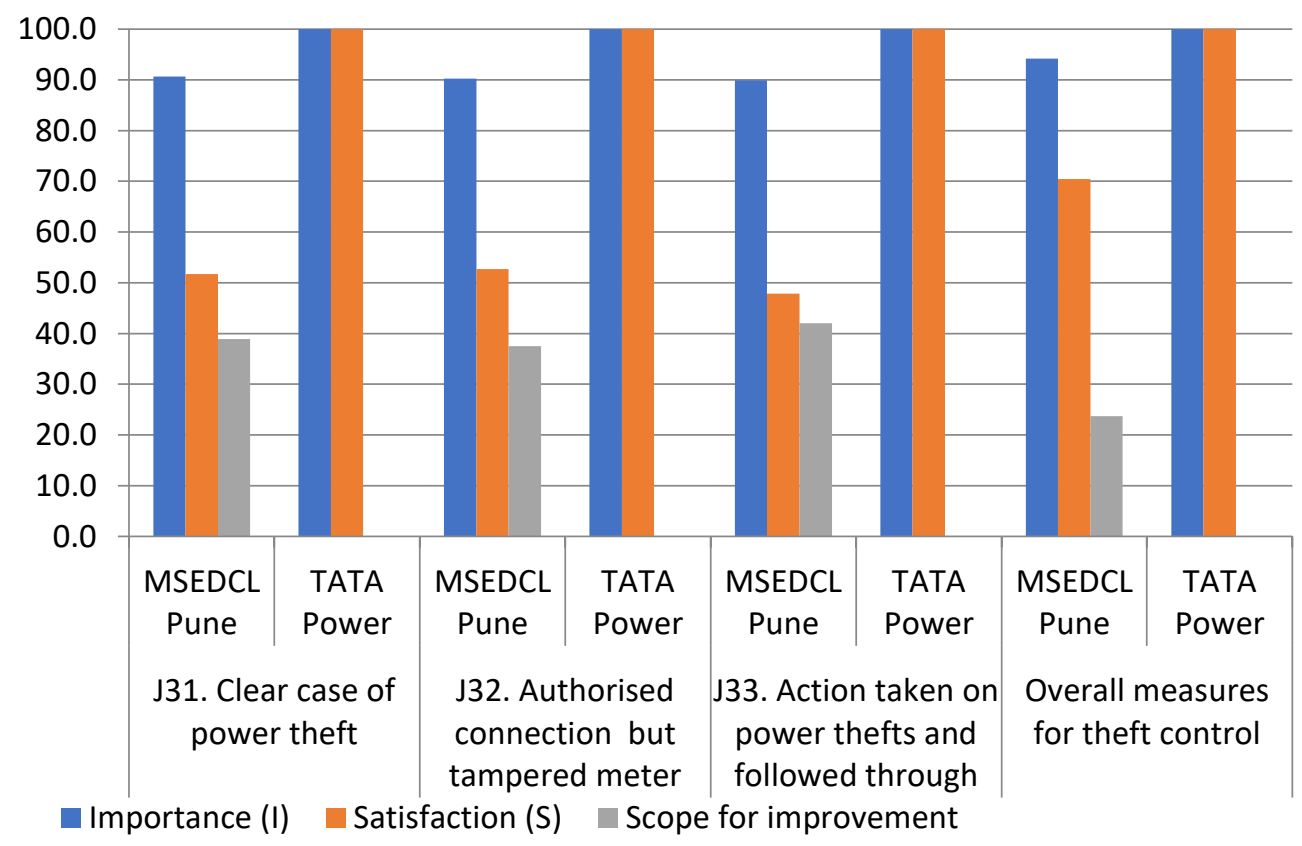

Fig. 20: Measures taken by electricity Distribution Company in detecting \& control of power thefts 


\section{Findings}

1. Zero gaps are observed in all three criterion for Tata Power.

2. Highest gap of -42.0 points is noticed in case of J33, action taken and followed through criterion for MSEDCL. Tata Power customers are fully satisfied for this criterion as there is zero gap. The scope for improvement therefore is 42.0 points.

3. In case of $\mathbf{J} 31$, clear case of power theft criterion a gap of -38.9 points is noticed in case of MSEDCL. This leaves a scope for improvement of 38.9 points as there is no gap observed in case of Tata Power.

4. For J32, authorized connection but tampered meter criterion, a gap of -37.5points was noticed in case of MSEDCL. The scope for improvement therefore was 37.5 points as there was zero gap observed in case of Tata Power.

5. Overall for this attribute, the scope for improvement was 39.5 points.

\section{Hypothesis}

Nullhypothesis Ho: MSEDCL's efforts to improve operations have lead to satisfaction of its customers Pune city

Alternate hypothesis H1: MSEDCL's efforts to improve operations have not lead to satisfaction of its customers Pune

\section{Hypothesis testing}

MSEDCL's efforts to improve operations of domestic customers was determined by MSEDCL's efforts such as: introduced photometer reading, started of electronic clearing system, introduced communication via internet, opened call centers, formed squads to detect and control power thefts and established consumer redressed forums for addressing consumer complaints.

Domestic customers were satisfied or not can be studied by asking the respondents on what were the expectations (importance) towards different components (attributes) of services offered by MSEDCL and how actually they were satisfied with services rendered by them.

Six attributes wise details are given below

Table 21. Reliability of photo meter reading. Under this criterion, the results were as given in the following Table. 22

\begin{tabular}{|l|l|l|l|l|l|l|l|}
\hline Criterion & \multicolumn{4}{|l|}{ Importance } & \multicolumn{2}{l|}{ Satisfaction } & 'Z' Value \\
\hline & Mean & S.D. & C.V. & Mean & S.D. & C.V. & \\
\hline $\begin{array}{l}\text { Reliability of meter } \\
\text { reading }\end{array}$ & 4.44 & 1.01 & 22.77 & 3.41 & 1.17 & 34.51 & 10.94 \\
\hline
\end{tabular}


Table 22. Reliability of electronic clearing system. The results under this criterion are as given in Table. 23 below

\begin{tabular}{|l|l|l|l|l|l|l|l|}
\hline Criterion & \multicolumn{3}{l|}{ Importance } & Satisfaction & ' 'Z'Value \\
\hline & Mean & S.D. & C.V & Mean & S.D. & \\
\hline $\begin{array}{l}\text { Reliability of electronic } \\
\text { clearing system }\end{array}$ & 4.39 & 1.00 & 22.93 & 3.30 & 1.22 & 37.07 & $11.35^{\prime \prime}$ \\
\hline
\end{tabular}

Table 23. Customer telephonic service. The results of this criterion are given in Table 24 below

\begin{tabular}{|c|c|c|c|c|c|c|c|}
\hline Criterion & ImpoI & & & Satisf & & & ' $Z$ ' Value \\
\hline & Mean & S D & $\mathrm{CV}$ & Mean & S D & $\mathrm{C} \mathrm{V}$ & \\
\hline $\begin{array}{l}\text { Customer telephonic } \\
\text { service }\end{array}$ & 3.94 & 9.20 & 81.26 & 2.28 & 1.01 & 44.44 & 8.12 \\
\hline
\end{tabular}

Table 24. Communication via the internet. The results of this criterion are given in the following Table 25

\begin{tabular}{|l|l|l|l|l|l|l|l|}
\hline Criterion & \multicolumn{4}{|l|}{ Importance } & \multicolumn{2}{l|}{ Satisfaction } & ' $Z$ ' Value \\
\hline & Mean & S.D. & C.V. & Mean & S.D. & C.V. & \\
\hline $\begin{array}{l}\text { Communication via the } \\
\text { internet }\end{array}$ & 3.8 & 1.41 & 54.75 & 2.57 & 1.41 & 54.75 & 10.13 \\
\hline
\end{tabular}

Table 25. easures taken in detecting and control of power thefts. The results of this attribute are given in the following Table 26

\begin{tabular}{|l|l|l|l|l|l|l|l|}
\hline Criterion & \multicolumn{2}{l|}{ Importance } & \multicolumn{2}{l|}{ Satisfaction } & \\
\hline & Mean & S.D. & C.V. & Mean & S.D. & C.V. & 'Z' Value \\
\hline Clear case of power theft & 4.53 & 0.95 & 20.99 & 2.58 & 2.11 & 81.83 & 13.84 \\
\hline $\begin{array}{l}\text { Authorised connection but } \\
\text { tampered meter }\end{array}$ & 4.51 & 0.95 & 21.08 & 2.63 & 2.23 & 84.69 & 12.74 \\
\hline $\begin{array}{l}\text { Action taken and followed } \\
\text { through }\end{array}$ & 4.49 & 1.04 & 23.15 & 2.39 & 1.09 & 45.69 & 22.90 \\
\hline
\end{tabular}


Table 26. Complaint handling system. The results of this attribute are as given in the Table 27 below

\begin{tabular}{|c|c|c|c|c|c|c|c|}
\hline Criterion & \multicolumn{3}{|c|}{ Importance } & \multicolumn{3}{|c|}{ Satisfaction } & 'Z' Value \\
\hline & Mean & S.D. & C.V. & Mean & S.D. & C.V. & \\
\hline $\begin{array}{l}\text { 1. Response to } \\
\text { customer needs }\end{array}$ & 4.51 & 0.91 & 20.20 & 2.74 & 1.11 & 40.44 & 19.69 \\
\hline $\begin{array}{l}\text { 2. Timely fault } \\
\text { attending }\end{array}$ & 4.54 & 0.86 & 19.13 & 2.78 & 1.12 & 40.30 & 20.48 \\
\hline $\begin{array}{l}\text { 3. Time taken for } \\
\text { administrative } \\
\text { procedures. }\end{array}$ & 4.05 & 0.90 & 22.20 & 2.64 & 1.01 & 38.49 & 17.12 \\
\hline $\begin{array}{l}\text { 4. Adequacy in } \\
\text { number of receiving } \\
\text { points. }\end{array}$ & 3.84 & 0.85 & 22.28 & 2.67 & 1.06 & 39.85 & 14.14 \\
\hline $\begin{array}{c}\text { 5. Speed at which } \\
\text { consumer grievance } \\
\text { related are handled. }\end{array}$ & 4.33 & 0.98 & 22.77 & 2.59 & 1.13 & 43.82 & 19.11 \\
\hline
\end{tabular}

It can be observed that for all six attributes:

a) Average score of importance was greater than average score of satisfaction.

b) Coefficient of variations for importance were less than coefficient of variations for satisfaction.

c) Hence variations in satisfaction were more.

d) ' $Z$ ' value for this criterion was more than the table value.

Therefore, for every attribute, customers and the importance but they were not satisfied. Hence it can be concluded that in general customers were not satisfied for all attributes.

\section{Limitations of the study}

1. Mainly due to power thefts, some respondents were reluctant to disclose information on power thefts 
2. Some respondents were not willing to give appointment due to security and confidentiality reasons.

3. The study covers only domestic customers. Industrial customers were not included,

\section{Scope for further research}

Area wise customer satisfaction levels for domestic customers can be found out for domestic customers in Pune city. Research can be carried out to determine customer satisfaction levels of commercial and industrial as well. Reliability Index can be found

\section{Conclusion}

Electricity distribution companies are now shifting from a monopoly to a competitive position through Government a regulation. The consumer will be king and will be able to pick and choose their distribution company like present position in automobile and aviation sectors in India. For, MSEDCL, there is maximum scope for improvements in case of power tariff and detection and control of power thefts.

\section{References}

[1] htpp://www.archieve.wn. com/2009/07/17/1400/ afghanistan energy.

[2] htpp://www jphtpp://criepi.denke

[3] htpp://www.article archives.com/company --- customer/ 708832-1.html

[4] htpp://www.cired.be/CIRED03/reports/R\% 206-28.pdf by G.REKETTYE.

[5] htpp://www.consumer international.org/---/4 D0EA5B4 - 0165 - 4510- 903 F - C9 F1

B8D 7642 -Energy WCRD 2006 backgrounder.pdf

[6] htpp://www. businesstoday. online.com/index.php?

[7] htpp://www.tdworld.com/customer_service/index x1.html.

[8] htpp://www.report. vattenfall.com/---customer + satisfaction.

[9] htpp://en.wikipedia.org/wiki/Customer_Satisfaction

[10] htpp://www.ieee.explore.ieee.org/ie15/7501/204110/00943071.pdf

[11] htpp:// www.mobiletech 4 social change.pbworks.com/f/mobtech.pptx

[12] htpp://www.edp.pt/EDPI/internet/ENGROUP/ About EDP al.

[13] htpp://www.analyticalq.com/energy/default.htm

[14] htpp://www.skippereil.com/ghana/ghana-home.aspx

[15] htpp://www.cired.be/CIRED 07/pdfs/CIRED 2007_0911_paper. Pdf

[16] htpp://www.heh.com/NR/rdonlyes/ A4DAE 419-D870--/ Ewf 107.pdf

[17] htpp://www.utilityweek.co.uk./features/uk/post - 1. Php

[18] htpp://www.usaid.gov

[19] htpp://www.jdpower.com

[20] htpp://www.reportlink.com/news

[21] htpp://www.mycustomer.com/downloads/jul09/92842

[22] htpp://www.ncsiuk.com/index.php?

[23] htpp://www.rru.worldbank.org/---/Namibia \% 20 Report \% 20 Final_\% 20 _7-3102_.pdf\] 
[24] htpp://www.ijonline.com/---/37804198 - bdf0 - 468c- a5de- 3359 ae3b 3129.pdf

- $\quad$ htpp://www.edp.pt/aedp/unidadesdenegico/---/DistribuicaoPT.aspx

- $\quad$ htpp:///www.gti.ktk.pte.hu/files/tiny_mce/File/---/ Cired

- $\quad$ Rekettye,G, Ordosdy,B \&, Terszty'anszky T. http://www.eh.gov.in

- $\quad$ htpp://www.eh.gov.hu

[28] htpp://www. scottishpower.com/p2.asp

[29] htpp://www.scottish-southern.co.uk/SSEInternet/index.aspx ? --- id---

[30] htpp://www.tdworld.com/customer-service /reliable-electric-award-0309

[31] htpp://www.the-atc.org/events/co9/---/BZ-Hakman-Selahattin-Sabanci.pdf dated 0106-2009

[32] htpp://www.tatapower.com

[33] htpp://www.tataenergyclub.com

[34] htpp://www.gis.esri.com/esripress/ shares/---/086_GAS \& ELEC_chapter 1 pdf.

[35] httpp://doi.org/10.1177/2278682116629538

\section{Books}

[36] Dutka, A. (1994) AMA Handbook for Customer Satisfaction, NTC, USA p, 43-45.

[37] Kurtkoti, Ashok(2015)Archer publishers, "A critical study of Customer Satisfaction Levels with specific reference to Maharashtra State Electricity Distribution Company Ltd. in Pune City." p 1-324

Journals

[38] Ashok Kurtkoti. (2012) Gavesana Journal of Management .Abstract of Doctoral dissertation : "A critical study of Customer Satisfaction Levels with specific reference to Maharashtra State Electricity Distribution Company Ltd. in Pune City.” ISSN P 89-90

[39] Dr. Ashok Kurtkoti ( December 2016) ' Advanced Management Compendium Summary of Ph.D. Thesis titled - A critical study of Customer Satisfaction Levels with specific reference to Maharashtra State Electricity Distribution Company Ltd. in Pune City , ISSN 2249-5681,P55-7575 